IFN Working Paper No. 818, 2010

\title{
The Futile Quest for a Grand Explanation of Long-run Government Expenditure
}

Dick Durevall and Magnus Henrekson 


\title{
The Futile Quest for a Grand Explanation of Long-Run Government Expenditure*
}

\author{
Dick Durevall $^{1}$ and Magnus Henrekson ${ }^{2}$
}

March 1, 2011

\begin{abstract}
This paper carries out a critical reappraisal of the two contending theories purporting to explain long-run government spending: Wagner's Law and different variants of the ratchet effect. We analyze data spanning from the early $19^{\text {th }}$ century until the present day in Sweden and the United Kingdom. Hence, in contrast to previous studies, we evaluate the validity of Wagner's Law and the ratchet effect hypothesis over a very long time period, starting at the beginning of industrialization. Cointegration analysis is used to investigate the long-run relationships between government expenditure and GDP, focusing on sub-periods and structural breaks. Moreover, we test the ratchet effect hypothesis by estimating models which allow for asymmetric adjustment. According to our main results, Wagner's Law does not hold in the long run, although the data are consistent with Wagner's Law between roughly 1860 and the mid 1970s. This can be traced to the formation of the modern public sector, including the introduction of public education, health care, and so forth. Yet Wagner's Law did not hold during the initial industrialization phase (before 1860), and in recent periods GDP only affects the government spending share when we control for population age structure. Finally, we find some evidence of asymmetric adjustment in the UK, particularly in the post-WWII period. However, the ratchet effect is not a general cause of the growth of government spending.
\end{abstract}

JEL Classification: H1; H55; I38.

Keywords: Displacement effect; Government expenditure; Growth of government; Public sector; Ratchet effect; Wagner's Law.

\author{
${ }^{1}$ Department of Economics \\ School of Business, Economics and Law \\ University of Gothenburg \\ P. O. Box 640 \\ SE- 40530 Gothenburg \\ SWEDEN \\ Phone +46-31-786 1350 \\ Fax +46-31-773 26 \\ e-mail: Dick.Durevall@economics.gu.se
}

\author{
${ }^{2}$ Research Institute of Industrial \\ Economics (IFN) \\ P. O. Box 55665 \\ SE-102 15 Stockholm \\ SWEDEN \\ Phone: +46-8-665 4502 \\ Fax: +46-8-665 4599 \\ e-mail: Magnus.Henrekson@ifn.se
}

\footnotetext{
* We are grateful for useful comments and suggestions from Henrik Jordahl, Alan Peacock, Thomas Piketty, Rati Ram, Richard Wagner, Joakim Westerlund and two anonymous referees, excellent research assistance from Robin Douhan and Daniel Hedblom, and for financial support from the Jan Wallander and Tom Hedelius Research Foundation.
} 


\section{Introduction}

The relative size of the public sector differs greatly across countries, even among those at similar income levels. For instance, the US, Japan and the Scandinavian countries are very similar in terms of per capita income, but the share of government spending was some 20 percentage points higher in the Scandinavian countries a few years into the new millennium. This suggests that the size of the public sector does not evolve in a subscribed pattern during the course of economic development, at least not within today's group of wealthy countries.

Nevertheless, the view that the public sector tends to grow in the long run relative to national income has become an accepted fact in public economics among many influential observers, including Atkinson and Stiglitz (1980, p. 326) and Easterly and Rebelo (1993), and in mainstream textbooks (e.g., Hindriks and Myles 2006, p. 79-80). According to Lindert (1996, p. 5) " $[\mathrm{t}]$ he notion that income growth will raise taxes and government spending, including social spending, is the most durable black box in the whole rise-of-the-state literature." This accords with $19^{\text {th }}$ century German social scientist Adolph Wagner's proposition (1893) that a positive relationship exists between the level of economic development and scope of government. Indeed, Wagner's proposition has increasingly gained the status of "law". In addition to casual empiricism, Wagner's Law has been tested empirically in both a time-series and cross-section framework; until the early 1990s, it received strong support with few exceptions.

Much fewer studies, however, analyze the major competing hypotheses seeking to explain any long-run tendency for increased government spending share: the displacement effect of Peacock and Wiseman (1961) and the ratchet effect of Bird (1971, 1972), where it is claimed that in a crisis $G$ declines more slowly than per capita income so that $G / Y$ rises, while the reverse is true in upturns. The rationale behind this effect is similar to Duesenberry's (1949) explanation of why consumption is more stable than income-current levels of $G$ constitute a frame of reference that make cutbacks difficult and therefore slows implementation in times of crisis. An alternative version of the ratchet effect is developed by Buchanan and Wagner (1978). It has the same implications as Bird's hypothesis, although it invokes public choice mechanisms involving politicians and bureaucrats taking advantage of the opportunity to increase the size of government. As we will explain in Section 2, these hypotheses are in fact very similar, at least observationally, and can be treated as variants of the same hypothesis. They share one central idea: relative government spending ratchets upward in times of crises 
(wars, social upheavals, recessions), and then remains at the new, higher level after society and the economy normalize.

This paper carries out a critical reappraisal of Wagner's Law and the ratchet/displacement hypothesis by analyzing data spanning from the early $19^{\text {th }}$ century to the present day in Sweden and the United Kingdom. In contrast to previous studies, we evaluate the validity of Wagner's Law from the beginning of industrialization until the present. Moreover, we compare two countries that have in many respects developed quite differently: Sweden can be regarded as the archetypal welfare state while the UK has become more of a "liberal market economy", following the example set by the US (Kitschelt et al. 1999). Government expenditure as a share of GDP differs a great deal; in 2006 it was $54.3 \%$ in Sweden and $43.5 \%$ in the UK, while in 1980 it was $60 \%$ in Sweden and $43 \%$ in the UK.

Complemented by graphical analysis, we use cointegration analysis to investigate the longrun relationships between government expenditure and GDP. Cointegration analysis is standard in recent literature, but in contrast to most other studies, we focus explicitly on structural breaks. Moreover, we evaluate the rival ratchet hypothesis by testing for asymmetric adjustment using a version of the approach developed by Hercowitz and Strawczynski (2004), which allows for long-run growth in the government expenditure share.

Our study differs from virtually all others in that we analyze a very long time span. ${ }^{1}$ Furthermore, in contrast to some recent papers like Shelton (2007), for example, we focus on within-country factors, rather than on those that mainly affect cross-country variations in the size of the public sector. Since the share of public expenditures in GDP varies between less than $10 \%$ to more than $60 \%$ in our data, variables such as the relative size of a country, ethnic and linguistic fractionalization and the type of constitution do not appear to be major causes of public sector growth.

Our main findings are similar for both countries: Strictly speaking, Wagner's Law does not hold in the long run. During both the major part of the $19^{\text {th }}$ century and the years since the

\footnotetext{
${ }^{1}$ One important exception is Lindert (2004a, 2004b) who focusses on explaining the long-term evolution of one major part of total spending, namely social spending. A further difference between our approach and Lindert's is that his approach is broader, relying on a mixture of econometric and careful institutional analyses, while we rely solely on time-series techniques, testing two influential and competing hypotheses purporting to explain the evolution of total relative government spending.
} 
mid-1980s, the public sector as a share of GDP shrunk or changed little, even as economic growth increased. There are, however, two time periods during which data are consistent with Wagner's Law: approximately 1860-1913 and 1920-1975 (World War I makes the period of 1914-1919 difficult to evaluate). Hence, Wagner's Law seems to have been irrelevant during the initial industrialization phase, 1800-1860 in Sweden and 1830-1860 in the UK, and the standard formulation of it cannot explain the evolution of the public sector share of GDP during recent periods, roughly since the 1970s.

We also find that changes in the age structure of the population explain why Wagner's Law does not hold after the mid-1980s. The decline in expenditure shares coincides with lowered dependency ratios in both countries. This finding corresponds with Shelton (2007), although his results indicate that it is the share of people aged 65 or older that gives rise to a positive correlation between income and government size, as social expenditure on retirees is larger in rich countries, while we find that the share of school-age children also is important.

Controlling for the dependency ratio reveals a stable relationship between government expenditure and GDP over the period 1920-2006. Still, this fact alone cannot salvage the standard version of Wagner's Law. Instead, it shows that the main implication of the Law is undermined by its own dynamics, as dependency on the age structure follows automatically when the public sector supplies services that are age-dependent, such as free education, child care, child allowances, and pensions. Moreover, age structure is to a large extent dependent on GDP per capita, as demonstrated by the theory of demographic transition (Caldwell 1976). In fact, the current old-age boom in the developed world is a result of demographic transition. Of course, Wagner did not know about the demographic transition, but as a consequence, Wagner's Law is of little use for making predictions on the future growth of the public sector without considering demographics.

There is some evidence of a ratchet effect in the inter-war period, where it seems to be a short-run phenomenon. The 1948-2006 period in the UK provides stronger evidence of an asymmetric effect, but it is generated by rapid growth of expenditure during good times; it does not result from short-run fiscal policy where recessions generate increases in government spending as a share of GDP, while expansions have little impact. In any case, the tests do not support the ratchet effect as a general explanation for the growth of government. Moreover, 
the finding of a ratchet effect does not preclude that Wagner's Law also is relevant for the same period, but it is not easy to disentangle the relative importance of either effect.

The paper is organized as follows. Section 2 discusses the main competing theories of longrun public expenditure. Section 3 provides a theoretical framework for the empirical analysis. Section 4 describes the data. Section 5 tests for Wagner's Law, and Section 6 tests for asymmetric adjustment/ratchet effects. Section 7 contains a discussion of our results and Section 8 concludes.

\section{Potential causes of the growth of government expenditure}

Wagner $(1883,1893)$ saw three main reasons for increased government involvement. ${ }^{2}$ First, in an increasingly complex society, the need for public protective and regulative activity would grow. In addition, urbanization and greater division of labor accompanying industrialization would require higher expenditures on contractual enforcement and law and order in order to guarantee the efficient performance of the economy. ${ }^{3}$

Second, Wagner argued that growth in real income would facilitate the relative expansion of income-elastic "cultural and welfare" expenditures. Education and culture were cited by Wagner in particular, noting that collective producers were in general more efficient than private ones.

Finally, he asserted that economic development and changes in technology required government to assume the management of natural monopolies in order to enhance economic efficiency. Similarly, the required scale of investment was in some cases so large (such as in railroads) that financing could not be handled appropriately within private joint stock companies. ${ }^{4}$

Wagner (1883, p. 7) explicitly states that "State expenditure may be higher, in absolute terms and as a percentage of national income": the higher the economic value of a

\footnotetext{
${ }^{2}$ See also Biehl (1998).

${ }^{3}$ Much the same ideas have been expounded by more recent authors. See, for example, Kuznets (1967) and North and Wallis (1982).

${ }^{4}$ Wagner's proposition cut against the prevailing view at the time. It was widely believed that the need for government activity and public interference into the private sphere would diminish as a result of man's moral and economic progress (Tarschys 1975).
} 
service, the higher its contribution to general productivity, and the higher the "free" national income, i.e., the part of national income remaining when the people's essential needs have been fulfilled. There is thus little doubt that Wagner was referring to an increasing share of government in GDP. Biehl (1998) has translated Wagner (1911) on "Economic Functions of the State" and there it is clear that Wagner both includes local government activity in his Law and he also explicitly mentions "the support of the poor, welfare, etc." In all, this suggests that Wagner had the ratio of total public expenditures to GDP in mind. A close examination of the literature also shows that this is the measure most scholars have in mind.

Up until the early 1990s, Wagner's Law received strong support with few exceptions. Since that time, however, over forty studies have been published, with very mixed results: about $35 \%$ fail to find evidence for Wagner's Law, while 30\% obtain support by controlling for other variables or focusing on specific types of expenditures, and 35\% obtain unqualified support for the hypothesis. ${ }^{5}$ As it happens, three recent papers illustrate these disparate results quite nicely: Shelton (2007) finds that demographic change in combination with social policy — not income - explains the share of government in GDP, while Akitoby et al. (2006) and Zaghini and Lamartina (2008) find support for Wagner's Law.

Furthermore, Lindert (1996) focuses on explaining the growth of social spending $(\approx$ half of total spending) in the early postwar period in 19 OECD countries. He finds that "the Wagner's Law idea barely survives" (p. 10). His main finding is that growth is mainly driven by two factors: (i) an aging population, but only up to a point - when the share of $65+$ exceeds a certain threshold the effect is weakened and eventually reversed, (ii) the degree to which the income distribution is more dispersed in the upper half relative to the lower half of the income distribution. ${ }^{6}$ Clearly, it has become necessary to determine why the results differ so much.

The first alternative to Wagner's Law was proposed by Peacock and Wiseman (PW) (1961) in their study of long-run government expenditure in the United Kingdom. PW observed that the expenditure likened a series of plateaus separated by peaks, and that these peaks coincided

\footnotetext{
${ }^{5}$ Appendix C contains a listing of these studies and the main finding(s) of each study. See also Henrekson (1992, Ch. 2), Easterly and Rebelo (1993) and Shelton (2007) for surveys.

${ }^{6}$ This idea has been refined in the "social affinity" theory (Kristov et al. 1992), which predicts that government redistribution will be greater, the wider the pre-tax income gaps above median and the lower the gaps below median income.
} 
with periods of war and preparations for war. Based on this observation, they developed the "displacement effect" hypothesis.

PW assumed that taxation remains fairly stable in peacetime. As a consequence, the limited revenue capacity of the government prevents major increases in expenditure. In peacetime, desired government expenditure and the limits of taxation are likely to diverge. During periods of social upheaval such as war, this divergence is likely to shrink, permanently displacing the burden of taxation upward. The end result is a higher expenditure plateau than before the onset of the upheaval. Formerly unacceptable revenue-raising methods are tolerated in times of crisis, and (it is claimed) the higher tax tolerance will persist even after the crisis subsides, thus enabling the government to implement expenditure programs that it previously desired but could not finance. Hence, the displacement effect asserts that the (horizontal) trend line will shift upward in discrete steps over time; these shifts are likely to be infrequent but fairly large.

Not before long, other scholars proposed that the upward ratchet effect occurs more often than suggested by PW. Bird $(1971,1972)$ argues that economic downturns tend to affect the share of government spending, resulting in upward ratcheting. As it takes time to adjust government spending plans downwards, a declining GDP, or slower GDP growth, increases the spending ratio. The rationale behind this effect is similar to Duesenberry's (1949) explanation of why consumption is more stable than income. The effect can also be motivated by reference to loss aversion and status quo bias (Kahneman et al. 1991). Buchanan and Wagner (1978) claim that such upward ratcheting can be explained by the Keynesian prescription of a countercyclical fiscal policy. In theory, the budget should be balanced over the business cycle; yet in practice, democratic politics gives rise to secular deficits in the absence of a binding fiscal constitution that demands that surpluses in booms are as large as deficits in recessions. Politicians strive to be reelected, and the direct benefits of government spending are easily identified while the indirect costs of deficit financing are far more diffuse and imperfectly understood.

Very few studies test directly for displacement or ratchet effects. Diamond (1977), for example, fails to find support for the displacement effect. Goff (1998) analyzes the degree of persistence of government expenditure to shocks on US data for 1889-1995 and finds support for a displacement/ratchet effect, particularly after 1930 and the beginning of "the New Deal 
era". Nevertheless, his results depend on the factors determining persistence, an issue he does not address in detail.

During recent years, however, a number of studies have analyzed the relationship between government expenditure and income during business cycles. In developed economies, public spending has been found to be countercyclical (Alesina et al. 2008) or procyclical or unrelated to business cycles (Talvi and Végh 2005). A few studies test for asymmetries in line with the displacement and ratchet effect, finding that spending increases more during expansions than it decreases during contractions (Gavin and Perotti 1997; Hercowitz and Strawczynski 2004). Hercowitz and Strawczynski (2004), who analyze a panel of developed countries for a recent period, interpret their finding as support for the Buchanan-Wagner hypothesis. However, they make clear that asymmetries only have a temporary effect on government expenditure shares.

\section{Theoretical framework for Wagner's Law and the ratchet effect}

Several functional forms have been used when testing for Wagner's Law (see, for example, Ram 1987). But as suggested by Michas (1975), Mann (1980) and Henrekson (1993), the following specification seems to capture the hypothesis:

$$
g s=\alpha+\beta(y p c)
$$

where $g s$ is the log of nominal public expenditure as a share of nominal GDP, $y p c$ is the $\log$ of real per capita GDP, and $\alpha$ and $\beta$ are coefficients. The coefficient of interest is $\beta$, which should be larger than zero according to Wagner's Law.

Eq. (1) is used by Shelton (2007) and is probably the most common formulation of Wagner's Law (e.g., Bohl 1996; Ahsani et al. 1996; Islam 2001; Chow et al. 2002). Most other equations are reformulations of Eq. (1). There is one alternative specification, used by Ram (1987), Goff (1998) and Ghate and Zak (2002), which consists of the relationship between real government expenditure and real GDP. By excluding population, however, it overlooks that increases in real income per capita — not GDP — are expected to generate a proportionally larger increase in the demand for public services. Moreover, the use of real government expenditure is questionable; Wagner's Law is a hypothesis describing the evolution of the government spending share, including the effect emanating from differences in productivity growth of government and private sector production. In addition, changes in public sector 
wages are not captured when real expenditure is used, since they are treated as price changes (Hercowitz and Strawczynski 2004).

It is important to interpret Eq. (1) as a long-run relationship between $g s$ and $y p c$. This means that the equation is not expected to hold at all times, but rather on average over a given time period. Moreover, for Wagner's Law to hold, $y p c$ has to determine $g s$. This does not preclude that government expenditure affects $y p c$, although it seems unlikely that it would determine per capita GDP in the long run, even though there could be a link via public investment. Fiscal policy, or using government expenditure to influence GDP growth, is not inconsistent with Wagner's Law either, although some claim it is (Biswal et al. 1999; Ziramba 2008). The reason is that the growth effects of fiscal policy are merely short to medium term.

Fiscal policy in combination with asymmetric responses can potentially generate a ratchet effect, which is a competing explanation for the growth of government. This hypothesis implies that the evolution of the expenditure share is merely the accumulated effect of shortrun asymmetric responses of government expenditures to temporary changes in output (Bird 1971, 1972; Diamond 1977). The hypothesis can be formulated as,

$$
g s_{t}=\alpha_{0}+\alpha_{1} g s_{t-1}+b_{1 P}(y p c-\tau)_{t}^{P}+b_{1 N}(y p c-\tau)_{t}^{N}
$$

where $(y p c-\tau)$ is deviation from trend, or the business cycle; $\tau$ is the trend in GDP per capita; $P$ and $N$ stand for positive and negative deviations from trend, or expansions and recessions. Thus, the hypothesis states that given $g s_{t-1}$, the expenditure share grows over time because recessions increase $g s$ more than expansions reduce it because of the asymmetry. A necessary requirement for the hypothesis to hold is that $b_{1 P}>b_{1 N}$, (or, if fiscal policy is countercyclical, $\left|b_{1 N}\right|>\left|b_{1 P}\right|$ ), which is testable given that we have an estimate of the trend, $\tau$. Note that $b_{1 P}$ and $b_{1 N}$ should be negative because of countercyclical fiscal policy, although procyclical policy cannot be ruled out; it seems to be common in developing countries (Alesina et al. 2008).

The displacement effect is related to the ratchet effect since it also implies that temporary increases in government expenditure have long-run effects, although there the focus lies on 
wars and other major social disturbances. ${ }^{7}$ We use graphs in Section 4 to illustrate that this effect is unlikely to explain the growth of government expenditure. Goff (1998), who tests the hypothesis on US data for 1889-1995, provides a more general interpretation of the displacement effect: any temporary shock to government expenditure could have a permanent or a highly persistent effect. With this interpretation, the empirical representation of the displacement effect is similar to Eq. (3):

$$
g s_{t}=\alpha_{0}+\alpha_{1} g s_{t-1}+\mu_{t}
$$

where $\mu$ is a stationary process measuring all sorts of shocks, $\alpha_{0}$ is the constant, and $\alpha_{1}$ is a coefficient equal or close to one. Hence, according to Eq. (3), an increase in $\mu_{t}$ raises $g s_{t}$ for a long period ( $\alpha_{1}$ is close to one) or permanently $\left(\alpha_{1}=1\right)$.

Goff finds that the displacement effect explains the evolution of government expenditure in the US. To account for the long-run growth in the government expenditure share, however, positive shocks have to be more common or larger than negative shocks. This is not captured by the models estimated; only the persistence of the shocks is tested. Furthermore, the tests are carried out in models with only one variable, so the observed persistence could be due to persistence in the excluded variables. Goff conducts some additional tests of persistence by estimating models that include real GDP, carrying out decompositions between long and short-run effects. However, population growth, as well as other factors, is ignored.

To test the hypotheses, we first estimate Eq. (1) and test for Wagner's Law. We then expand the equation by including population structure, which has been neglected in most studies on Wagner's Law. Two exceptions are Lindert (1996) and Shelton (2007). Thereafter, we use graphs to describe the data based on Eq. (3). This simple approach makes it possible to cast serious doubt on the validity of the displacement hypothesis. In order to test the ratchet effect hypothesis, we estimate models based on Eq. (2) and test the hypothesis $b_{1 P}>b_{1 N}$.

\section{The data}

We use annual time series data that comprise the years 1800-2006 for Sweden and 18302006 for the UK. The data are described in detail in Appendix B. When analyzing data over a

\footnotetext{
${ }^{7}$ Diamond (1977), Tussing and Henning (1979) and Henrekson (1990) test the displacement effect econometrically.
} 
long historical period, data quality becomes an issue. Although there is little we can do to improve quality, historical macro data have been used in a number of earlier studies with some success (e.g., Englund et al. 1992 and Bergman et al. 1992 for Sweden, and Castle and Hendry 2009 for the UK).

Except for Sweden before 1914 - a time period during which no data on transfer spending exist - we use total government gross expenditure, including military expenditures. Although many researchers have preferred to analyze non-military expenditures, we do not advocate this. First, non-military expenditures are not independent of spending on military goods and services (Wiseman and Diamond 1975). Second, during periods without war or imminent threats of war, decisions for both military and non-military spending are probably based on the same information or generated by similar mechanisms. Third, military expenditures do not seem to dominate the long-term growth of total expenditures when we test with available data. Finally, short-term increases in military expenditures due to war do not generally influence the interpretation of econometric results, since we focus on the long run. The exceptions are World War I and World War II, particularly for the UK. However, these wars would affect the results even if military expenditures were excluded.

Figures 1 and 2 depict the development of the ratio of government expenditure to GDP in Sweden and the UK. The data are reported separately for 1800-1913 and 1920-2006 because the Swedish series on government expenditure does not include transfers before 1914, and because the increase in UK expenditure during WWI was so large that it affects the interpretability of the graph.

Figure 1 shows government expenditure for Sweden (1800-1913) and the UK (1830-1913) as a share of GDP. It declines during most of the $19^{\text {th }}$ century in both countries, but starts to increase in the 1870s. The evolution of the two series is thus quite similar. The major differences are probably due to wars: the sharp drop in Sweden in 1810 can be traced to reduced government expenditures and rapid economic growth after the peace treaty with France in 1807 and the end of the war with Russia in 1809; the sharp decline in the UK in the mid-1850s follows the termination of the Crimean War (1852-1856), while the upsurge in expenditure at the turn of the century is largely the result of the Boer War (1899-1902). Note also that in both countries the expenditure shares are lower in the 1910s than in the first half of the $19^{\text {th }}$ century. 
Figures $1-8$ about here

Figure 2 depicts the same series for 1920-2006. Again, the overall development is quite similar. In both countries, the expenditure shares show a positive trend until the 1980s, although there are large deviations due to WWII, particularly in the UK. Then the trend growth peters out, even turning sharply negative in Sweden in 1992-2006. Before the 1990s, Sweden has a clearly higher average growth rate than the UK, but the expenditure ratio was markedly higher in the UK until the mid-1950s. In 2006, the ratio was roughly 15 percentage points higher in Sweden than in the UK.

Figures 3 to 8 depict government expenditure as a share of GDP and real GDP per capita. The series are in logs and show potential relationships indicated by Eq. (1). It is evident from Figures 3 and 5 that Wagner's Law did not hold during most of the $19^{\text {th }}$ century. The share of government expenditure declined during the first half of the 1800s in Sweden, remained stable for about 30 years, and then grew slowly during 1880-1913; at the same time, GDP grew almost continuously. Although the UK data is only available from 1830, the pattern is similar.

In an oft-cited paper, Oxley (1994) finds that Wagner's Law holds in Britain in 1870-1913. Oxley limits his analysis to 1870-1913 for two reasons: a) economic growth was rapid during this period, making Wagner's Law more likely to hold; and b) WWI caused a structural break that is econometrically hard to handle. The first motivation is doubtful because GDP per capita growth in Britain was higher in 1831-1869 (0.9\%) than in 1870-1913 (0.8\%); furthermore, picking a favorable period is likely to bias the test of the hypothesis. Nevertheless, by highlighting 1870-1913, Figures 4 and 6 give reason to believe that Wagner's Law might hold in both countries during this period.

Figures 7 and 8 depict the period 1920-2006. There are large deviations between the series in both countries, but in the period beginning after WWII the expenditure share and real GDP per capita seem to grow at the same speed. This development ends roughly in the mid-1980s. During recent years, the expenditure share has been stable in the UK and declined in Sweden, while per capita GDP has increased in both countries, casting doubt on the relevance of Wagner's Law for recent decades. 


\section{Cointegration analysis}

To verify that the conclusions from the visual inspection of Figures $1-8$ hold, we test for the presence of long-run relationships, i.e., if Eq. (1) is an adequate description of the data. All series are highly persistent, and we treat them as integrated of order one. Dickey-Fuller (1981) unit root tests, reported in Table 1A in Appendix A, indicate that this is a reasonable assumption. The existence of a long-run relationship, and the sign and size of the coefficient of interest, $\beta$, can thus be tested with cointegration analysis. Yet, acceptance or rejection of Wagner's Law does not hinge on whether the series contain unit roots or not. If the series are trend stationary with structural breaks - which is the most likely alternative hypothesisWagner's Law could still hold, given that they have common breaks and that government expenditure grows faster than GDP when real GDP per capita grows.

To test for cointegration we use both the Engle-Granger (1987) test, and the Gregory Hansen (1996) test that allows for a structural break at an unknown date. The tests require that at most one cointegrating vector exists and that the common factor restriction on the dynamics holds (Ericsson and MacKinnon 2002). These requirements seem to be fulfilled: we only have two variables, so there cannot be more than one cointegrating vector; furthermore, autoregressive distributed lag models, which include dynamics, give similar long-run solutions as the Engle-Granger procedure. Testing for cointegration with Fully Modified OLS, which corrects for bias in case $y p c$ is not weakly exogenous, produces practically the same long-run relationships.

The Gregory-Hansen test is used since Figures 3 to 8 indicate that there might be shifts in the relationship between government expenditure and real GDP per capita. It has the same null hypothesis as the Engle-Granger test, no cointegration, but the alternative is cointegration with or without a structural break. Thus, if both tests reject the null, we know there is cointegration without a structural break, but if only the Gregory-Hansen test rejects the null, we know there is cointegration with one structural break.

A drawback of the Gregory-Hansen test is that it is designed to detect one break only, and it might have little power when there are more breaks. We therefore carry out the tests sequentially, starting with the pre-WWI and post WWI samples and then divide them up into shorter periods when it is more likely there is cointegration. The shorter samples are based on reported break dates and visual inspection of graphs (Figures 3-8). 
There are a number of potential outliers in the series, so we initially used the dummy saturation procedure in Autometrics. This is a computer-automated general-to-specific modeling approach, which in principle tests all possible reduction paths and eliminates insignificant variables while keeping the chosen significance level constant. ${ }^{8}$ Dummy saturation is a procedure that tests for outliers by including a dummy for each observation (Castle and Hendry 2009; Santos 2008). We used 0.1\% as the critical value. The significant dummies were then aggregated with their coefficients as weights, and used in the cointegration tests. Only WWII outliers in the UK model turned out to affect the results substantively, so we report cointegration tests without dummy variables for all the other time periods. The period of WWI is excluded from the analysis.

The upper panels of Tables 1 and 2 report the estimates of Eq. (1) and cointegration test statistics for Sweden (1800-2006) and the UK (1830-2006). ADF is the Engle-Granger cointegration test statistic, and $A D F^{*}$ is the Gregory-Hansen test statistic for a full regime shift $(\mathrm{C} / \mathrm{S})$, i.e., a change in both the intercept and coefficient of the explanatory variable. We also carried out level-shift tests, but they do not provide any additional information. We report break dates for all time periods but they are mainly of interest when the Gregory-Hansen test is significant and the Engle-Granger test is insignificant. The number of lags used in the tests is based on their $t$-values: a lag is included if it is significant at the 10 percent critical value. In most cases the choice of lags was obvious and no result hinges on including too few lags. Since we have few observations, and the test statistics only are correct asymptotically, we also report the estimated roots from the Engle-Granger tests.

The cointegration tests for period before WW1 support the conclusions drawn from visual inspection of Figure 3-6. The Engle-Granger tests are insignificant in both countries; the estimate of the elasticity, $\beta$, is negative, i.e., -0.16 in Sweden and -0.67 in the UK, and the roots are close to unity. The Gregory-Hansen test shows there is cointegration when we allow for a regime shift, in 1860 in Sweden and 1864 in the UK. We then split the samples and test the period 1800-1959 and 1860-1913 in Sweden, and 1830-1863 and 1864-1913 in the UK. In the period before the 1860 s, there seems to be cointegration in both countries, though only

\footnotetext{
${ }^{8}$ See Doornik (2008) for a description of Autometrics.The methodology is based on Hoover and Perez (1999) and Hendry and Krolzig (2001). Castle and Hendry (2009) and Ericsson and Kamin (2009) are two applications of automated general-to-specific modelling.
} 
when allowing for a break in the UK, due to the Crimean War in 1853. However, $\beta$ is negative, -1.15 and -1.36 . This implies that the expenditure share decreases as GDP grows, so there is no support for Wagner's Law.

The period after 1860 is more supportive of Wagner's Law, though the evidence for Sweden is weak; the Engle-Granger test is significant at the 10 percent level only, while the GregoryHansen test is insignificant, and $\beta$ is small, 0.17 . For the UK the support is stronger; both tests are significant at the 5 percent level and $\beta$, is 0.86 . This verifies the finding of Oxley (1994).

We then turn to the 1920-2006 data. The test is clearly significant for Sweden in 1920-2006, providing support for Wagner's Law: the estimate of $\beta$ is 0.73 . However, if we split the sample into the two periods, based on the break date indicated by Gregory-Hansen, 19201973 and 1974-2006, it becomes evident from both tests that the two variables are cointegrated over the first but not the second period. Moreover, $\beta$ is -0.04 during $1974-$ 2006.

Tables 1 and 2 and Figures 9 and 10 about here

The results for the UK differ somewhat, but not much. The Engle-Granger test is insignificant for 1920-2006, while the Gregory-Hansen test is significant at the 10 percent level. It indicates there is a break in 1973. We thus re-estimate the model over 1920-1972 and 19732006. As in Sweden, Wagner's Law holds in the first period, but not in the second, where the estimate of $\beta$ also is negative -0.07 .

Figure 9 shows the deviations from the long-run relationship, i.e., the cointegrating relation, for Sweden over 1920-2006, gs+9.53-0.73ypc. Even if Wagner's Law holds in the long run according to the test, the deviations are highly persistent during certain periods, as also indicated by the negative sign of $\beta$ in the period 1974-2006. Figure 10 shows that the pattern in the UK is similar, even though the cointegration test is not significant without allowing for a structural break. In practice, Wagner's Law thus does not seem to be useful for understanding the growth of government expenditures, particularly not after the 1970s. 


\subsection{Wagner Law and population structure}

The literature on Wagner's Law rarely considers the age structure of the population, even though it should affect expenditure. However Shelton (2007), after analyzing cross-country panel data for 1970-2000, concludes that Wagner's Law is driven by demographics, particularly the share of population aged $65+$. This means that the coefficient on income is positive and significant in his version of Eq. (1), but becomes insignificant when the demographic variable is included.

Since a number of policy reforms have been implemented during the last 60 years that should have substantially strengthened the link between government expenditure and the age structure, we evaluate the role of the dependency ratio. It is defined as those aged 0-19 and $65+$, divided by those aged 20-64. This measure should capture spending on child care, schooling and pensions, as well as other expenditures. Figures 11 and 12 depict the deviation from the long-run relationship for 1965-2006 (based on the estimates for 1920-2006 in Table 1 and 2) and the dependency ratio in Sweden and the UK. There seems to be a tight relationship. The definition of the dependency ratio and the year 1965 are ad hoc; using 0-14 instead, for example, works better for the 1950s, but worse for the 1990s. The reduction in the dependency ratio could thus potentially explain the decline in expenditure as a share of GDP during recent years.

Figures 11 and 12 about here

The lower panels of Table 1 and 2 report cointegration tests for Eq. 1, including the dependency ratio. In the case of the UK, adding the dependency ratio to the models for 19202006 makes all the tests significant at the 1 percent critical level. We have already established cointegration for 1920-2006 for Sweden, so dependency is only added for consistency. Nonetheless, it captures the large swing in the cointegrating vector visible in both countries (Figure 11 and 12). In fact, Wagner's Law does not hold for this period without the dependency ratio (upper panel in Table 1 and 2). Adding the dependency ratio makes the Engle-Granger test significant and reduces the roots from 0.96 to 0.66 in Sweden and from 0.88 to 0.59 in the UK. We also report tests with the dependency ratio for 1974-2006 and 1973-2006; there is cointegration in both cases and $\beta$ is now positive, although relatively small in the UK. 
To check whether the dependency ratio is of consequence for the pre-WWI period, we use the ratio of people $0-14$ and $65+$ to people aged $15-64$, since this definition should be more relevant in the past. The models are estimated for 1800-1913, 1800-1859 and 1860-1913 for Sweden, and 1841-1913 for the UK, the period for which we have data. However, the dependency ratio has a minor impact, and adding it does not alter the earlier findings.

To conclude, we find long-run relationships for 1920-2006 in both Sweden and the UK, where real per capita GDP enters with a significant and positive coefficient ( 0.73 in Sweden and 0.56 in the UK). However, this is true only after controlling for the dependency ratio: without the dependency ratio, the relationship between government expenditure and GDP can hardly be characterized as stable. Strictly speaking, it is incorrect to interpret this finding as support for Wagner's Law - it only holds in the UK, and possibly Sweden, for 1864-1913, and from 1920 to the 1970 s.

It could be argued that the finding shows how Wagner's Law is undercut by its own dynamics, since dependency on the age structure follows automatically when the public sector supplies services that are age-dependent, such as free education, child care, child allowances, pensions, and so forth. Furthermore, the age structure is to a large extent dependent on GDP per capita in the long run, as demonstrated by the theory of demographic transition (Caldwell 1976). This interpretation of the role of demographics differs from Shelton (2007), who argues that it is the age structure in combination with social security spending that generates the relation between $g s$ and $y p c$. However, this result probably arises from Shelton's relatively short sample period (1970-2000), but merits further study.

On the other hand, the interpretation, that Wagner's Law fails because controlling for the age structure is required to reveal cointegration, is arguably harsh. But it shows that the mechanism linking per capita income to government size is more complex than Wagner hypothesized; the cointegrating relationship is not stable and sometimes depends on the inclusion of age demographics, and there are structural breaks in the cointegrating relationships.

\section{Testing for the displacement and ratchet effect}

In this section we first use graphs to illustrate that the originally suggested displacement effect (Peacock and Wiseman 1961) has little empirical support. Then we test the more general 
version of the displacement effect, namely the ratchet effect of Bird $(1971,1972)$ and Buchanan and Wagner (1978).

We present three figures to illustrate the relevance of PW's displacement effect, plotting the government expenditure share of GDP and its past peak value. A minimum requirement for the effect to be valid, and thus substantively important, is the existence of occasional sharp increases in $g s$ which are not followed by commensurate declines.

Figure 13 depicts data for Sweden in 1800-2006; we have combined the two series in 1921 by scaling up the 1800-1920 spending ratio by the difference between the series in $1921 .{ }^{9}$ No displacement effect can be detected before WWI, but government spending during WWI seems to have created displacement since it did not return to its pre-war level. After WWII, the rapid and continuous expansion of expenditure in the 1950s and 1960s swamped any sign of displacement. There are two peaks after WWII, in 1982 and 1993, both of which related to economic crises. They did not, however, generate any discernible displacement effect; rather, the crises were followed by a reduction in the spending share.

Figures 13, 14 and 15 about here

Figure 14 shows the evolution of $g s$ in the UK in 1830-2006. There is clearly displacement in connection to WWI, but such an effect can only be detected after WWII when the underlying trend is ignored (see also Henrekson 1990). This evidence of displacement is not surprising, since the wars inspired PW to form their hypothesis in the first place. Because the sharp increase in the expenditure share during WWI so dominates the picture, Figure 15 depicts the period 1950-2006. The expenditure share grows from the late 1950s until 1981-82 and then drops to the level of the mid-1970s. Hence, the data do not indicate that the displacement effect drove growth in relative public spending after WWII.

The ratchet effect can be interpreted as a generalized version of the displacement effect (Goff 1998). For the ratchet effect to act as an alternative explanation to Wagner's Law, however,

\footnotetext{
${ }^{9}$ The method of combining the pre- and post-1920 Swedish series is innocuous as long as transfers are largely constant for some time following 1920. Transfers as a share of GDP are highly stable in the 1920s. They are $3.4 \%$ of GDP in 1918, decrease slightly in 1919-1921, and then stabilize around 3\% until 1930. It is not until 1931 in the wake of the Great Depression that transfers begin to increase, but the increase is still fairly modest: from $3.1 \%$ of GDP in 1930 to $4.3 \%$ in 1938 (Henrekson 1992).
} 
the evolution of the expenditure share should merely result from the accumulated effect of short-run asymmetries. The writings of Bird (1971, 1972) and Diamond (1977) do not clearly elucidate this fact. The finding of cointegration, albeit with the inclusion of the dependency ratio, therefore casts doubts on the ratchet effect as the only driver of the growth of government expenditure. Both Bird and Buchanan-Wagner were looking to explain the evolution of government spending in the richest countries during the first quarter century following WWII. But can the pattern they (casually) observed be expected to apply over longer periods and highly varying conditions, or were the first decades of the postwar period unique in this respect? This is an interesting question that we now address below.

When testing the ratchet effect hypothesis, Goff (1998) focuses on the persistence of shocks to government expenditures. We prefer to explicitly model the impact of recessions and expansions on the growth of government expenditure, following Diamond (1977) and the literature on business cycles and fiscal policy (see Hercowitz and Strawczynski 2004). We estimate the following model,

$$
\begin{aligned}
\Delta g S_{t}= & \alpha_{0}+\alpha_{1} \Delta g S_{t-1}+\alpha_{2} \Delta g s_{t-2}+b_{1 P}(y p c-\tau)_{t}^{P}+b_{2 P}(y p c-\tau)_{t-1}^{P} \\
& +b_{1 N}(y p c-\tau)_{t}^{N}+b_{2 N}(y p c-\tau)_{t-1}^{N}+v_{t}
\end{aligned}
$$

where $\alpha_{0}$ is a constant, $\tau$ potential output, $(y p c-\tau)^{P}$ a measure of periods of high income per capita relative to trend (good times) and $(y p c-\tau)^{N}$ a measure of periods of low income per capita relative to trend (bad times). Two lags of $\Delta g s$ and some dummies, as described below, are included to ensure that the error term, $v_{t}$, is roughly white noise.

The model differs from Diamond (1977) in two ways. First, we allow for dynamics by including lags in line with Hercowitz and Strawczynski (2004), while Diamond estimates a static model. Second, we calculate $\tau$ using the Hodrick-Prescott filter; the adjustment parameter is set to 6.25 as recommended by Ravn and Uhlig (2002). Diamond (1977) uses the growth rate of output as a measure of business cycles, while our approach is a common way to measure cyclicality (Lane 2003; Alesina et al. 2008).

The ratchet effect hypothesis implies that government expenditure is on average asymmetric over the business cycle; accordingly, the decline in the expenditure ratio, $g s$, is smaller 
during good times than the increase during bad times. Using Eq. (4), we can evaluate the hypothesis by calculating the steady-state solution

$$
\begin{aligned}
\Delta g S & =\alpha_{0} /\left(1-\alpha_{1}-\alpha_{2}\right)+\left[\left(b_{1 P}+b_{2 P}\right) /\left(1-\alpha_{1}-\alpha_{2}\right)\right](y p c-\tau)^{P} \\
& +\left[\left(b_{1 N}+b_{2 N}\right) /\left(1-\alpha_{1}-\alpha_{2}\right)\right](y p c-\tau)^{N} \\
& =a+\beta_{P}(y p c-\tau)^{P}+\beta_{N}(y p c-\tau)^{N}
\end{aligned}
$$

where the terms in brackets are the coefficients of interest, summarized as $\beta_{P}$ and $\beta_{N}$. For the ratchet effect to hold, it is necessary that $\beta_{P}>\beta_{N}$. The hypothesis is easiest to understand if fiscal policy is assumed to be countercyclical, since then both coefficients are negative.

According to Eq. (4), business cycle fluctuations can generate immediate (within a year) adjustments in government expenditures; this is usually considered an adequate measure of fiscal policy (Alesina et al., 2008). In this case, the hypothesis would be $\left[b_{P} /\left(1-\alpha_{1}-\alpha_{2}\right)\right]>\left[b_{N} /\left(1-\alpha_{1}-\alpha_{2}\right)\right]$. However, it is possible that the adjustment process is slow or that the initial response is corrected the following year, so lags of $(y p c-\tau)^{P}$ and $(y p c-\tau)^{N}$ could also influence government expenditure. This is allowed for in the model estimated by Hercowitz and Strawczynski (2004).

We divide the samples into two major time periods: 1803-1913 (1833-1913 for the UK) and 1923-2006; and four sub-periods, before and after the break in the 1860s, and before and after WWII. The division of the samples is partly based on the results of the cointegration tests in Table 1 and partly on Buchanan and Wagner (1978), who argue that the ratchet effect is the result of Keynesian active fiscal policy after WWII. When required, the models have impulse dummies for large outliers due to the termination of the Russian War 1809 (Sweden), the Crimean War 1854-1856 (UK), and World War II. Some other observations can also be considered outliers, but we prefer to report specifications without them. The results do not hinge on correcting for outliers, except for WWII.

Tables 3 and 4 report the estimates of Eq. (4) for Sweden and the UK. The tables show estimates and $t$-values for the $b$ s and the steady state values $\beta_{P}$ and $\beta_{N}$, and $\beta_{P}-\beta_{N}$, two $\chi^{2}(1)$ distributed Wald test statistics, the null hypotheses that there is no difference between $\beta_{P}$ and $\beta_{N}$, and between $b_{2 P}$ and $b_{2 N}$. 
Tables 3 and 4 about here

It is striking that most of the steady state coefficients in Table 3 and 4 have positive signs, indicating procyclical fiscal policy. The positive signs are due to the coefficients on lagged $(y p c-\tau)^{P}$ and $(y p c-\tau)^{N}$, which except one, are positive. It is however more likely that that lags act as proxies for cointegrating relations where the trend $\tau$ captures a combination of variables, including $g s$, than picking up slow short-run fiscal policy responses. The terms $(y p c-\tau)_{t-1}^{P}$ and $(y p c-\tau)_{t-1}^{N}$ seem to function as error correction terms, since gs grows when lagged output is high relative to trend, and vice versa. In fact, when we replace the lags regressions in Table 3 and 4 with error correction terms, based on the cointegration analysis in the previous section, all coefficients on $(y p c-\tau)_{t}^{P}$ and $(y p c-\tau)_{t}^{N}$ are negative, indicating countercyclical policy. Moreover, the error correction terms are all highly significant (results available on request). Nonetheless, since at least one of the lags is significant in each equation, they should not be excluded from the analysis, even though it is not standard in the literature on fiscal policy and business cycles to include lags. ${ }^{10}$

The results for Sweden in the pre-WWI period show that the contemporaneous responses, $b_{1 P}$, and $b_{1 N}$, and lagged responses in good times, $b_{2 P}$, are small and insignificant, while coefficients on the lagged response in bad times are positive, relatively large, and significant (Table 3). Focusing on the individual coefficients, the only substantial response seems to be a reduction of expenditure during bad times, though the differences between the steady state coefficients are insignificant according to the test. Hence, there is no support for a ratchet effect.

The estimates of the contemporaneous responses during the post WWI period are all negative, indicating countercyclical fiscal policy. Responses during bad times, $b_{1 N}$, are large in absolute terms and significant, while responses during good times, $b_{1 P}$, are small and insignificant, so there appears to be some asymmetry. On the other hand, all lagged responses are positive,

\footnotetext{
${ }^{10}$ Hercowitz and Strawczynski (2004) use the growth rate of GDP net of trend as their measure of business cycles, so their use of lags does not create a problem. We de-trend the log-level of GDP since this is consistent with the ratchet hypothesis. In most studies on fiscal policy and business cycles no lags are used. See, for example, Alesina et al. (2008) and Gavin and Perotti (1997).
} 
clearly significant in five out of six cases, and of roughly the same magnitude as indicated by the test that $b_{2 P}-b_{2 N}=0$. The differences between the steady state coefficients are tiny for 1920-2006 and 1952-2006, ${ }^{11}$ but positive and relatively large for 1923-1936, $\beta_{P}-\beta_{N}=1.78$. The large value is an indication of a ratchet effect. However, the test for asymmetry is not significant.

In the UK, the results for the pre-WWI period differ somewhat from Sweden: there seems to have been countercyclical policy during bad times, at least according to the estimates for 1833-1913 and1865-1913 (Table 4). Moreover, the the lagged responses are positive and large for both good and bad times, and fairly similar since the tests of $b_{2 P}-b_{2 N}=0$ are insignificant. The differences between the steady state terms are large, which mainly is due to the differences between the contemporaneous coefficients. Nonetheless, the test for $\beta_{P}-\beta_{N}=0$ are insignificant.

There is stronger evidence for asymmetry during the interwar and post-WWII period, although there is a high degree of symmetry when the model is estimated over both periods, 1923-2006. The interwar period in the UK is similar to the one in Sweden, large contemporaneous response during bad times and none during good times, and large and similar lagged responses. In contrast to Sweden, the test for difference in steady state values is clearly significant, because of the contemporaneous coefficients.

The post-WWII period in the UK provides the strongest evidence in favor of asymmetry: the difference of the steady state values is large, 2.74 , and it is significant at the $10 \%$ critical level, and the test for difference of the coefficients on lagged values is significant at the $5 \%$ critical level. In contrast to the pre-WWII period, the contemporaneous coefficients are similar, and the asymmetry is due to relatively large increases during good times, which can be viewed as adjustment to long-run levels. Hence, it is not entirely consistent with the ratchet hypothesis of Bird (1971, 1972) and Buchanan and Wagner (1978). Nevertheless, we calculated how much asymmetry explains of the growth of the expenditure share from 1948 to 1984 , a period of rapid growth. It added close to 10 percentage points, or $70 \%$ of the total growth.

\footnotetext{
${ }^{11}$ The model is estimated for 1952-2006 since the observations for 1948-1951 can be considered outliers.
} 
Although our results have to be interpreted tentatively, they do not support the ratchet effect as a general explanation for the growth of government. In fact, this was already established by the finding of cointegration in the previous section. They do provide support for short-run asymmetric countercyclical policy, except for the pre-WWI period in Sweden, but in most cases subsequent adjustments remove the asymmetry. There is some evidence of a ratchet effect in the interwar period, but the samples are small and the results are thus uncertain. There is evidence of asymmetry for 1948-2006 in the UK, which is robust to reasonable changes in the sample, addition of lags, and an error correction term. However, it is not due to a ratchet effect where $G / Y$ rises more in recessions than it declines during booms.

\section{Discussion}

An obvious question to ask is why Wagner's Law holds in some periods only, notably the 4050 years preceding WWI and the first 30-35 years after WWII. The late $19^{\text {th }}$ century is an era of increased political enfranchisement. Meltzer and Richard (1983) and Lindert (1994, 2004a) propose that government grows when the franchise is extended to include more voters below the median income (the decisive voter), when the growth of incomes provides revenues for increased redistribution and when the income distribution becomes more uneven. Then government grows because there is a difference between the political and the market processes. The market produces a distribution of income less equal than the distribution of votes, so those with the lowest incomes use the political process to implement redistributional programs in their own favor. This idea has been further refined in the "social affinity" theory (Kristov et al. 1992), which predicts that government redistribution will be greater, the wider the pre-tax income gaps above median and the smaller the gaps below median income. Lindert (1996) finds support for this theory in the 1960-81 period in the OECD.

Strong growth in the late $19^{\text {th }}$ century in both countries also made it possible for the governments to introduce a system of income tax collection around the year 1900, which, once introduced, is far more cost-efficient than a system based on customs and excise taxes (Levi 1988). It therefore allows an expansion of government that is not possible under a more primitive tax collection regime. This can either be seen as a supply side explanation (Holcombe 2005), or as a factor that eases the financing constraint for the government so that it can more easily cater to the demand of their citizens. 
The greatest expansion of the spending share takes place after WWII, lasting some 35 to 40 years. Wagner's Law receives strong support during this period in both countries. Real income expands rapidly and government spending relative to GDP increases by roughly 20 and 40 percentage points, respectively. This development is abruptly reversed, and the decline in the spending ratio is particularly large in Sweden, where the spending share declines by almost 10 percentage points. This coincides with rapid real income growth.

Many observers - e.g., Cameron (1978), Lindbeck (1976), Rodrik (1998) and Ram (2009)— stress the importance of the open economy for the growth of government. ${ }^{12}$ However, our findings of abrupt reversals are not consistent with this proposition. Although it applies in the first era of increased economic integration (1860-1913) and during most of the post-WWII period, it does not hold for the most recent period of increased integration (post 1990). ${ }^{13}$

Although our regressions show that a decline in the dependency ratio can "explain" why the government spending ratio did not grow in the UK and Sweden recently, it is still true that if Wagner's Law really holds then the spending share should grow when per capita income rises, irrespective of demography. But over time structural and technological changes have increased the scope for non-government production of social services, and private agents can use insurance and financial markets to handle many desired redistributions across individuals and over the life cycle. ${ }^{14}$

Countries have also chosen different institutional arrangements. Esping-Andersen (1990) identifies three broad welfare models: the Scandinavian, the Continental European and the Anglo-Saxon one. Historical chance has often determined who has become responsible for the financing and provision of a certain service (the individual, her employer, the government or a non-government organization such as the church or the trade unions). Moreover, this can be changed by political decisions such as the Swedish pension reform in the early 1990s, which greatly reduced the government's share of pension payments by capping payments at a fairly

\footnotetext{
${ }^{12}$ Several mechanisms are proposed: Openness is said to result in a high industrial concentration, which fosters a climate where unions can thrive and have a decisive influence on government, and government expenditure may serve as a form of insurance against external risk.

${ }^{13}$ From 1990 to 2006 exports plus imports as a share of GDP increased from 60 to 94\% of GDP in Sweden and from 50 to $60 \%$ of GDP in the UK (OECD, Country Statistical Profiles 2010, retrieved Oct. 19, 2010).

${ }^{14}$ Bergh (2005) calculates that $75 \%$ of all redistributive transfers in Sweden concern life cycle redistributions for the same individual. Large part of such transfers can be handled in other ways, notably by private agents or through mandatory personal savings accounts (Fölster 1997).
} 
low level and making outgoing pensions directly related to the current aggregate wage sum in the economy (Palme 2005).

More generally, the effects of different historical choices regarding financing and provision on relative government spending are likely to be particularly large with respect to services where demand is highly income-elastic and when the services suffer from Baumol's Cost Disease. Higher education, child care and care of the elderly are good cases in point. ${ }^{15}$ In fact, this is broadly consistent with Wagner's own writings, where he distinguishes between two purposes of the State: "law and power" and "culture and welfare". In the latter domain, according to Wagner (1911; cited from Biehl 1998, p. 108-109) "there does not exist the same need for uniformity, concentration and centralization of the provision of services by public authorities; in this sphere partly the opposite is true. Here, other public bodies are providing services jointly with or instead of the State. ... Nevertheless, this expansionary tendency [of the State] too has the character of a development law."

Disincentive effects of a large government sector will set in sooner or later, and according to many observers such effects were apparent in both countries by the mid 1970s, but severe structural crises were required before relative government spending was lowered. ${ }^{16}$ Since the early to mid 1990s there has been a great deal of deregulation of product markets, and globalization has strongly increased the competitive pressure both on firms and tax bases (Sinn 1998; Bergh and Karlsson 2010). Moreover, as emphasized by Lindert (2004a), hightax societies in general, and Sweden in particular, have been able to design the tax and transfer systems more efficiently than low-tax countries, thereby reducing the deadweight costs that are expected to arise from higher relative spending. ${ }^{17}$

\section{Conclusion}

We have tested existing theories purporting to explain the long-run evolution of government expenditure as a share of income. There are two main rival theories: Wagner's Law, which is a demand-side explanation, and ratchet effect hypotheses, which emphasize either larger

\footnotetext{
15 See also Thomsson (2010) who discusses why the US has a comparatively small government sector, but instead a large "private welfare state" with employment-based benefits. OECD (2007) provides extensive comparisons of systems for child care and parental leave.

${ }^{16}$ See Crafts (1991) for the UK and Freeman et al. (1997) and Lindbeck (1997) for Sweden.

${ }^{17}$ Lindert (2004a) pushes this point hard, making the controversial claim that given the astute design of tax and spending policies in many large government countries, the welfare state has turned out to be "a free lunch".
} 
crises (wars and other social upheavals) or shorter crises (recessions and economic downturns) in claiming that relative government spending ratchets upward during a crisis and stays at a higher level when the economy recovers. The latter effect has been motivated by reference to path dependence, status quo bias, and public choice mechanisms involving politicians and bureaucrats taking advantage of the opportunity to increase the size of government. If the ratchet effect exists, it is thus an empirical regularity that can be explained by referring to both supply and demand side factors.

Innumerable studies test Wagner's Law, and a few test for the ratchet effect. In contrast to these earlier studies, we use extremely long time series: 207 years for Sweden and 177 years for the UK. We also emphasize the structural breaks of the estimated models and use charts to support our findings.

It is evident that neither Wagner's Law nor the ratchet effect hypotheses receive general support. There are two distinct episodes of growth in relative government spending where Wagner's Law holds: some 40-50 years preceding WWI and a period of 30-35 years after WWII. To obtain a relationship between income and government spending for more recent periods we need to control for the age structure. ${ }^{18}$

There is no consistent evidence of a ratchet effect in either country. There is some evidence of an asymmetric effect in both countries in the interwar period, but it is only significant in the UK, and the samples are very small. The UK post-war period provides stronger evidence of an asymmetric response, but the asymmetry seems to be due to rapid upward adjustment in spending during good times, not to a ratchet effect where governments exploit recessions and crises to permanently shift the government spending ratio upwards. Moreover, this finding does not preclude that Wagner's Law also is relevant for the same period, but it is not easy to disentangle the relative contribution of each effect.

So, is Holcombe (2005) correct in his pessimistic and cynical conclusion that citizens are manipulated by politicians and government bureaucrats who would like to increase their

\footnotetext{
${ }^{18}$ One anonymous referee pointed out that one should not expect Wagner's Law to hold in periods before modernization sets in. This is arguably the case for the earliest period in Sweden (before ca 1865), and the fact that we do not find support for the Law during that period in Sweden may not be held as evidence against Wagner. We agree that this argument carries some weight. However, in the UK, modernization started several decades before and economic growth per capita was relatively fast in the 1830-1869 period.
} 
power over our incomes and garner resources for themselves? The answer is no. It is clear that demand plays a significant role, but so do the agendas of politicians and bureaucrats. We know from other research that the opportunity to tax is restrained by the negative incentive effects that set in, particularly at high levels of government spending. Moreover, politicians are forced to consider what the electorate wants in order to legitimate the taxes levied and their own positions and entitlements. ${ }^{19}$ Thus, there are no simple explanations for the long-run evolution of relative government spending, an argument made already by Wagner and Weber (1977). Rather, the evolution is governed by a complex interplay between supply and demand factors, and deep-seated changes in underlying structural conditions over time.

To conclude, based on long-run evidence from two representative countries-Sweden and the UK - it appears that Wagner's Law is not a stylized fact for how economies behave in the long run, although it seems to hold reasonably well over a period when the economy goes through a process of modernization. Neither does the ratchet hypothesis provide an adequate explanation for the long-term evolution of the government spending ratio. More complex explanations are called for, and our study suggests that these explanations are likely to vary strongly both over time and across countries.

\footnotetext{
${ }^{19}$ See Royed (1996) for the UK and Naurin (2009) for Sweden, and the discussion in Lindert (2004a) on the many mechanisms used in high-tax countries to reduce the negative incentive effects.
} 


\section{Appendix A: Complementary table}

Table 1A: Dickey-Fuller unit root tests

\begin{tabular}{lccc}
\hline Sweden & $t_{\mathrm{ADF}}$ & lags & time period \\
$g s$ & -3.02 & 1 & $1802-1913$ \\
$y p c$ & -1.44 & 2 & $1803-1913$ \\
$\Delta g s$ & $-11.64 * * *$ & 0 & $1801-1913$ \\
$\Delta y p c$ & $-9.33^{* * *}$ & 1 & $1802-1913$ \\
$g s$ & -3.14 & 1 & $1922-2006$ \\
$y p c$ & -2.06 & 1 & $1922-2006$ \\
$\Delta g s$ & $-6.38 * * *$ & 0 & $1922-2006$ \\
$\Delta y p c$ & $-7.00^{* * *}$ & 0 & $1922-2006$ \\
United Kingdom & & & \\
$g s$ & -2.29 & 1 & $1832-1913$ \\
$y p c$ & -3.46 & 1 & $1832-1913$ \\
$\Delta g s$ & $-8.79 * * *$ & 0 & $1832-1913$ \\
$\Delta y p c$ & $-12.57 * * *$ & 0 & $1832-1913$ \\
$g s$ & -3.38 & 1 & $1922-2006$ \\
$y p c$ & -2.71 & 1 & $1922-2006$ \\
$\Delta g s$ & $-5.31^{* * *}$ & 0 & $1922-2006$ \\
$\Delta y p c$ & $-7.76^{* * *}$ & 0 & $1922-2006$ \\
\hline
\end{tabular}

Note: The equations in log-levels contain a constant and a trend and the equations in first differences contain a constant. $* * *$ indicates rejection at $1 \%$ level.

\section{Appendix B: Data sources and definitions}

\section{Sweden (1920-2006)}

Data on total government expenditure for the period 1920-49 are from Höök (1962) and Krantz (1987). GDP data for 1920-49 are from Krantz and Nilsson (1975) and for 1950-59 from the Swedish National Accounts published by Statistics Sweden. For 1950-2006 all expenditure and price data are from the Swedish National Accounts. Population data are from Statistiska Centralbyrån (1969) and Statistical Abstract of Sweden.

GDP data for the years 1960-2006 are from OECD Economic Outlook, OECD Main Economic Indicators (retrieved on-line from the Source OECD database).

\section{United Kingdom (1920-2006)}

All data for the period 1920-60 are from Feinstein (1972). Data for the years 1961-2006 come from OECD Economic Outlook, OECD Main Economic Indicators (both retrieved online from the SourceOECD database). Population statistics for the calculation of the age dependency ratios are from UK National Statistics.

\section{Data for 1800-1930}

Except where otherwise indicated, the source is Mitchell (2007). Text in italics refers to the specific headline where the statistics may be found in that book. 


\section{Sweden (1800-1930)}

Population: Mid-year Population Estimates.

Dependent population: Defined by the entire population younger than 15 or 65 and older.

Own calculations from Population of Countries by Sex and Age Groups.

Government expenditure: Total government consumption and investments in current prices. Government transfers are unavailable before 1913. Source: Krantz (1987), Krantz and Nilsson (1975).

GDP: Gross domestic product at market prices, current prices. National Account Totals. Mitchell uses data from Krantz and Nilsson (1975) for the period 1861-1950.

Real GDP: Gross domestic product at market prices, constant (1908/09) prices. National Account Totals. Mitchell uses data from Krantz and Nilsson (1975) for the period 18611950.

GDP (1800-1860): Gross domestic product by expenditure, purchasers' prices in current value. Source: Edvinsson (2005).

\section{United Kingdom (1830-1930)}

Population: Mid-year Population Estimates. England + Wales and Scotland aggregates.

Dependent population: Defined by the entire population younger than 15 or 65 and older. Own calculations from Population of Countries by Sex and Age Groups. England + Wales and Scotland aggregates.

Government expenditure: Total central government gross expenditure in current prices, capital items (including debt redemption) is excluded. As far as possible, all kind of government expenditure are included in this table. Total Central Government.

GDP: Gross domestic product in current prices at factor cost. Estimates constructed from expenditure sources. National Account Totals.

Real GDP: Gross domestic product in constant (1900) prices at factor cost. Estimates constructed from expenditure sources. National Account Totals.

\section{Appendix C: Classification of studies since 1990 testing Wagner's Law (updated through October 2010)}

\section{Studies finding support for Wagner's Law}

\footnotetext{
Ahsan, Syed M., Andy C. C. Kwan and Balbir S. Sahni (1996), “Cointegration and Wagner's Hypothesis: Times-series Evidence for Canada.” Applied Economics 28(1), 1955-1058.

Akitoby, Bernardin, Benedict Clements, Sanjeev Gupta and Gabriela Inchauste (2006), "Public Spending, Voracity, and Wagner's Law in Developing Countries." European Journal of Political Economy 22(4), 908-924.

Bairam, Erkin I. (1992), “Variable Elasticity and Wagner's Law.” Public Finance 47(3), 491-495.
} 
Hayo, Berndt (1996), "Testing Wagner's Law for Germany: An Exercise in Applied Time Series Analysis." Jahrbuch für Nationalökonomie und Statistik 213(3), 329-343.

Iniguez-Montiel, Alberto (2010), “Government Expenditure and National Income in Mexico: Keynes versus Wagner.” Applied Economics Letters 17(9), 887-893.

Islam, Anisul M. (2001), "Wagner's Law Revisited: Cointegration and Exogeneity Tests for the USA." Applied Economics Letters 8(8), 509-515.

Kalam, Mohammad Abul, and Nusrate Aziz (2009), "Growth of Government Expenditure in Bangladesh: An Empirical Enquiry into the Validity of Wagner's Law.” Global Economy Journal 9(2).

Karagianni, Stella, and Maria Pempetzoglou (2009), "Evidence for Non-linear Causality between Public Spending and Income in the European Union Countries.” Journal of Applied Business Research 25(1), 69-82.

Kolluri, Bharat R., Michael J. Panik and Mahmoud S. Wahab (2000), "Government Expenditure and Economic Growth: Evidence from G7 countries.” Applied Economics 32(8), 1059-1068.

Lin, Chi-Ang (1995), “More Evidence on Wagner's Law for Mexico.” Public Finance 50(2), 267-277.

Mohammadi, Hassan, Murat Cak and Demet Cak (2008), "Wagner's Hypothesis: New Evidence from Turkey Using the Bounds Testing Approach.” Journal of Economic Studies 35(1), 94-106.

Murthy, N. R. Vasudeva (1993), "Further Evidence of Wagner's Law for Mexico: An Application of Cointegration Analysis." Public Finance 48(1), 92-96.

Nagarajan, P., and Annie A. Spears (1990), “An Econometric Test of Wagner's Law for Mexico: A Reexamination.” Public Finance 45(1), 165-168.

Narayan, Paresh Kumar, Arti Prasad and Baljeet Singh (2008), “A Test of Wagner's Hypothesis for the Fiji Islands." Applied Economics 40(19-21), 2793-2801.

Oxley, Les (1994), "Cointegration, Causality and Wagner's Law: A Test for Britain 1870-1913.” Scottish Journal of Political Economy 41(3), 286-298.

Ram, Rati (1992), “Use of Box-Cox Models for Testing Wagner's Hypothesis: A Critical Note.” Public Finance 47(3), 496-504.

Zaghini, Andrea, and Serena Lamartina (2008), "Increasing Public Expenditures: Wagner's Law in OECD Countries.” CFS Working Paper No. 2008/13, Center for Financial Studies, University of Frankfurt.

\section{Studies finding qualified support for Wagner's Law $^{20}$}

Arpaia, Alfonso, and Alessandro Turrini (2008), "Government Expenditure and Economic Growth in the EU: Long-run Tendencies and Short-term Adjustment.” European Commission Economic Papers 300, Brussels.

Asseery, Ahmed A., David Law and Nicholas Perdikis (1999), “Wagner's Law and Public Expenditure in Iraq: A Test Using Disaggregated Data.” Applied Economics Letters 6(1), 39-44.

Bairam, Erkin I. (1995), “Level of Aggregation, Variable Elasticity and Wagner's Law.” Economics Letters 48(3), 341-344.

Biswal, Bagala, Urvashi Dhawan and Hooi-Yean Lee (1999), “Testing Wagner versus Keynes Using Disaggregated Public Expenditure Data for Canada.” Applied Economics 31(10), 1283-1291.

Bohl, Martin T. (1996), “Some International Evidence on Wagner's Law.” Public Finance 51(2), 185-200.

Chang, Tsangyao (2002),"An Econometric Test of Wagner's Law for Six Countries Based on Cointegration and Error-correction Modelling Techniques.” Applied Economics 34(9), 1157-1169.

Chow, Ying-Foon, John A. Cotsomitis and Andy C. C. Kwan (2002), "Multivariate Cointegration and Causality Tests of Wagner's Hypothesis: Evidence from the UK.” Applied Economics 34(13), 1671-1677.

Courakis, Anthony S., Fatima Moura-Roque and George Tridimas (1993), "Public Expenditure Growth in Greece and Portugal: Wagner's Law and Beyond." Applied Economics 25(1), 125-134.

Olekalns, Nilss (1999), ”Demographics and Wagner's Law. Evidence from OECD Countries.” Research Paper No. 694, Department of Economics, University of Melbourne.

\footnotetext{
${ }^{20}$ We classify studies as providing qualified support for Wagner's Law if they need to include additional variables to find cointegration or if the hypothesis only holds for some types of expenditures or countries.
} 
Osaretin Iyare, Sunday and Troy Lorde (2004), “Co-integration, Causality and Wagner's Law: Tests for Selected Caribbean Countries.” Applied Economics Letters 11(13), 815-825.

Payne, James E., and Bradley T. Ewing (1996), “International Evidence on Wagner's Hypothesis: A Cointegration Analysis.” Public Finance 51(2), 258-274.

Thornton, John (1999), “Cointegration, Causality and Wagner's Law in 19th Century Europe.” Applied Economics Letters 6(7), 413-416.

\section{Studies not finding support for Wagner's Law}

Babatunde, M. Adetunji (2008), "Establishing Wagner's Law in the West Africa Monetary Zone (WAMZ): Investigation Using the Bounds Test.” Indian Economic Journal 56(3), 109-123.

Burney, Nadeem A. (2002), "Wagner's Hypothesis: Evidence from Kuwait Using Cointegration Tests.” Applied Economics 34(1), 49-57.

Chletsos, Michael, and Christos Kollias (1997), “Testing Wagner's Law Using Disaggregated Public Expenditure Data in the Case of Greece: 1958-93.” Applied Economics 29(3), 371-377.

Ghate, Chetan, and Paul J. Zak (2002), "Growth of Government and the Politics of Fiscal Policy." Structural Change and Economic Dynamics 13(4), 435-455.

Gao, Yanyan (2008), "Government Size and Economic Development: A World Panel Data Analysis Based on the Substitution between Government and Market." Available at SSRN: http://ssrn.com/abstract=1322043

Hayo, Bernd (1994), “No Further Evidence on Wagner's Law for Mexico.” Public Finance 49(2), $287-294$.

Halicioglu, Ferda (2003), “Testing Wagner's Law for Turkey 1969-2000.” Review of Middle East Economics and Finance 1(2), 129-141.

Henrekson, Magnus (1993), ”Wagner's Law - A Spurious Relationship?” Public Finance 48(3), 406-415.

Huang, Chiung-Ju (2006a), “Government Expenditures in China and Taiwan: Do They Follow Wagner's Law?" Journal of Economic Development 31(2), 139-148.

Huang, Chiung-Ju (2006b), "Testing Wagner's Law Using Bounds Test and a New Granger Non-Causality Test: Evidence for Taiwan.” Journal of American Academy of Business 8(2), 86-90.

Katrakilidis; Constantinos, and Persefoni Tsaliki (2009), "Further Evidence on the Causal Relationship between Government Spending and Economic Growth: The Case of Greece, 1958-2004." Acta Oeconomica 59(1), $57-78$.

Kolluri, Bharat R., and Mahmoud Wahab (2007), "Asymmetries in the Conditional Relation of Government Expenditure and Economic Growth.” Applied Economics 39(16-18), 2303-2322.

Narayan, Paresh K., Ingrid Nielsen and Russel Smyth (2008), "Panel Data, Cointegration, Causality and Wagner's Law: Empirical Evidence from Chinese Provinces.” China Economic Review 19(2), 297-307.

Shelton, Cameron A. (2007), "The Size and Composition of Government Expenditure.” Journal of Public Economics 91(11-12), 2230-2260.

Wahab, Mahmoud (2004), "Economic Growth and Government Expenditure: Evidence from a New Test Specification.” Applied Economics 36(19), 2125-2135.

Ziramba, Emmanuel (2008), “Wagner's Law: An Econometric Test for South Africa, 1960-2006.” South African Journal of Economics 76(4), 596-606.

\section{References}

Ahsan, Syed M., Andy C. C. Kwan and Balbir S. Sahni (1996), “Cointegration and Wagner's Hypothesis: Times-series Evidence for Canada.” Applied Economics 28(1), 1955-1058.

Akitoby, Bernardin, Benedict Clements, Sanjeev Gupta and Gabriela Inchauste (2006), "Public Spending, Voracity, and Wagner's Law in Developing Countries.” European Journal of Political Economy 22(4), 908-924.

Alesina, Alberto, Filipe R. Campante,and Guido Tabellini (2008), "Why Is Fiscal Policy Often Procyclical?" Journal of the European Economic Association 6(5), 1006-1036.

Atkinson, Anthony B. and Joseph E. Stiglitz (1980), Lectures on Public Economics. New York: McGraw-Hill. 
Bergh, Andreas (2005), “On Inter- and Intra-individual Redistribution of the Welfare State." Social Science Quarterly 86(5), 984-995.

Bergh, Andreas, and Martin Karlson (2010), “Government Size and Growth: Accounting for Economic Freedom and Globalization." Public Choice, 142(1-2): 195-213.

Bergman, Michael, Stefan Gerlach and Lars Jonung (1992), "External influences in Nordic Business Cycles, 1870-1988." Open Economies Review 3(1), 1-22.

Biehl, Dieter (1998), Wagner's Law: An Introduction to and a Translation of the Last Version of Adolph Wagner's Text of 1911." Public Finance 53(1); 102-111.

Bird, Richard M. (1971), “Wagner's 'Law' of Expanding State Activity.” Public Finance 26(1), 1-26.

Bird, Richard M. (1972), “The 'Displacement Effect': A Critical Note.” Finanzarchiv 30(3), 454-463.

Biswal, Bagala, Urvashi Dhawan and Hooi-Yean Lee (1999), “Testing Wagner versus Keynes Using Disaggregated Public Expenditure Data for Canada.” Applied Economics 31(10), 1283-1291.

Bohl, Martin T. (1996), "Some International Evidence on Wagner's Law." Public Finance 51(2), 185-200.

Buchanan, James M., and Richard E. Wagner (1978), “The Political Biases of Keynesian Economics.” In Gordon Tullock, ed., Fiscal Responsibility in Constitutional Democracy. Studies in Public Choice, Vol. 1. Leiden and Boston: Martinus Nijhoff.

Caldwell, John C. (1976), “A Restatement of Demographic Transition Theory.” Population and Development Review 2(3/4), 321-366.

Cameron, David (1978), “The Expansion of the Public Economy: A Comparative Analysis.” American Political Science Review 72(4), 1243-1261.

Castle, Jennifer L., and David F. Hendry (2009), "The Long-run Determinants of UK Wages, 1860-2004." Journal of Macroeconomics 31(1), 5-28.

Chow, Ying-Foon, John A. Cotsomitis and Andy C. C. Kwan (2002), "Multivariate Cointegration and Causality Tests of Wagner's Hypothesis: Evidence from the UK.” Applied Economics 34(13), 1671-1677.

Crafts, Nicholas F. R. (1991), "Reversing Relative Economic Decline? The 1980s in Historical Perspective." Oxford Review of Economic Policy 7(3), 81-98,

Dickey, David A., and William A. Fuller (1981), "Likelihood Ratio Statistics for Autoregressive Time Series with a Unit Root." Econometrica 49(4), 1057-1072.

Diamond, Jack (1977), "Econometric Testing of the Displacement Effect: A Reconsideration.” Finanzarchiv 35(3), 389-404.

Doornik, Jurgen A. (2008), “Autometrics.” In: Jennifer L. Castle and Neil Shephard, eds., The Methodology and Practice of Econometrics: A Festschrift in Honour of David F. Hendry. Oxford: Oxford University Press.

Duesenberry, James S. (1949), Income, Saving and the Theory of Consumer Behavior. Cambridge, MA: Harvard University Press.

Easterly, William, and Sergio Rebelo (1993), Fiscal Policy and Economic Growth: An Empirical Investigation." Journal of Monetary Economics 32(3), 417-458.

Edvinsson, Rodney (2005), Growth Accumulation Crisis, With New Macroeconomic Data for Sweden 18002000. Stockholm: Almqvist \& Wiksell International.

Ericsson, Neil R., and James G. MacKinnon (2002), "Distributions of Error Correction Tests for Cointegration." Econometrics Journal 5(2), 285-318.

Ericsson, Neil R.,and Steven B. Kamin (2009), "Constructive Data Mining: Modelling the Argentinean Broad Money Demand" chap. 17 in The Methodology and Practice of Econometrics: A Festschrift in Honour of David Hendry, Eds. Jennifer Castle and Neil Shephard, Oxford University Press

Engle, Robert F., and Clive W. Granger (1987), "Co-Integration and Error Correction: Representation, Estimation and Testing.” Econometrica 55(2), 251-276.

Englund, Peter, Torsten Persson and Lars E. O. Svensson (1992), "Swedish Business Cycles: 1861-1988." Journal of Monetary Economics 30(3), 343-371.

Esping-Andersen, Gøsta (1990), The Three Worlds of Welfare Capitalism. Cambridge: Polity.

Fölster, Stefan (1997), "Social Insurance Based on Personal Savings Accounts: A Possible Reform Strategy for Overburdened Welfare States." Kyklos 50(2), 253-258.

Feinstein, Charles H. (1972), National Income, Expenditure and Output of the United Kingdom 1855-1965. Cambridge: Cambridge University Press.

Freeman, Richard B., Robert Topel and Birgitta Swedenborg, eds. (1997), The Welfare State in Transition. Chicago: University of Chicago Press. 
Gavin, Michael, and Roberto Perotti (1997), "Fiscal Policy in Latin America." In Ben S. Bernanke and Julio Rotemberg, eds., NBER Macroeconomics Annual 12, 11-72.

Ghate, Chetan, and Paul J. Zak (2002), “Growth of Government and the Politics of Fiscal Policy.” Structural Change and Economic Dynamic 13(4), 435-455.

Goff, Brian (1998), "Persistence in Government Spending Fluctuations: New Evidence on the Displacement Effect." Public Choice 97(1-2), 141-157.

Gregory, Allan W., and Bruce E. Hansen (1996), "Residual-based Tests for Cointegration in Models with Regime Shifts.” Journal of Econometrics 70(1), 99-126.

Hendry, David F., and Hans-Martin Krolzig (2001), Automatic Econometric Model Selection. London: Timberlake Consultants Press.

Henrekson, Magnus (1990), "Peacock and Wiseman's Displacement Effect: A Reappraisal and a New Test.” European Journal of Political Economy 6(3), 245-260.

Henrekson, Magnus (1992), An Economic Analysis of Swedish Government Expenditure. Aldershot: Avebury.

Henrekson, Magnus (1993), ’Wagner's Law - A Spurious Relationship?” Public Finance 48(3), 406-415.

Hercowitz, Zvi, and Michel Strawczynski (2004), "Cyclical Ratcheting in Government Spending: Evidence from the OECD." Review of Economics and Statistics 86(1), 353-361.

Hindriks, Jean, and Gareth M. Myles (2006), Intermediate Public Economics, Cambridge, MA: MIT Press.

Holcombe, Randall G. (2005), “Government Growth in the Twenty-first Century.” Public Choice 124(1), 95114.

Höök, Erik (1962), Den offentliga sektorns expansion. En studie av de offentliga civila utgifternas utveckling 1913-58. Stockholm: Almqvist \& Wiksell.

Hoover, Kevin D., and Stephen J. Perez (1999), "Data mining Reconsidered: Encompassing and the General-tospecific Approach to Specification Search.” Econometrics Journal 2(2), 167-191.

Islam, Anisul M. (2001), "Wagner's Law Revisited: Cointegration and Exogeneity Tests for the USA." Applied Economics Letters 8(8), 509-515.

Kahneman, Daniel, Jack L. Knetsch, and Richard H. Thaler (1991), “Anomalies: The Endowment Effect, Loss Aversion, and Status Quo Bias." Journal of Economic Perspectives 5(1), 193-206.

Kitschelt, Herbert P., Peter Lange, Gary Marks and John D. Stephens, eds. (1999), Continuity and Change in Contemporary Capitalism. Cambridge and New York: Cambridge University Press.

Krantz, Olle (1987), Historiska nationalräkenskaper för Sverige: Offentlig verksamhet 1800-1980. Lund: Studentlitteratur.

Krantz, Olle, and Carl-Axel Nilsson (1975), Swedish National Product 1861-1970. New Aspects on Method and Measurement. Lund: CWK Gleerup.

Kristov, Lorenzo, Peter H. Lindert and Robert McClelland (1992), "Pressure Groups and Redistribution." Journal of Public Economics 48(2), 135-163.

Kuznets, Simon S. (1967), Modern Economic Growth. New Haven: Yale University Press.

Lane, Philip R. (2003), “The Cyclical Behavior of Fiscal Policy: Evidence from the OECD.” Journal of Public Economics 87(12), 2661-2675.

Levi, Margaret (1988), Of Rule and Revenue. Berkeley, CA: University of California Press.

Lindbeck, Assar (1976), "Stabilization Policy in Open Economies with Endogenous Politicians." American Economic Review 66(2), 1-19.

Lindbeck, Assar (1997), “The Swedish Experiment.” Journal of Economic Literature 35(3), 1273-1319.

Lindert, Peter H. (1994), “The Rise of Social Spending, 1880-1930?” Explorations in Economic History 31(1), $1-34$.

Lindert, Peter H. (1996), “What Limits Social Spending?” Explorations in Economic History 33(1), 1-34.

Lindert, Peter H. (2004a), Growing Public: Volume 1, The Story: Social Spending and Economic Growth since the Eighteenth Century. Cambridge and New York: Cambridge University Press.

Lindert, Peter H. (2004b), Growing Public: Volume 2, Further Evidence: Social Spending and Economic Growth since the Eighteenth Century. Cambridge and New York: Cambridge University Press.

Mann, Arthur J. (1980), “Wagner's Law: An Econometric Test for Mexico, 1925-1976.” National Tax Journal 33(2), 189-201.

Meltzer, Alan H., and Scott F. Richard (1983), "Tests of a Rational Theory of the Size of Government." Public Choice 41(3), 403-418. 
Michas, Nicholas A. (1975), "Wagner's Law of Public Expenditures: What is the Appropriate Measurement for a Valid Test?" Public Finance 30(1), 77-84.

Mitchell, Brian R. (2007), International Historical Statistics 1750-2005, Vol. 3. 6th ed. New York: Palgrave Macmillan.

Naurin, Elin (2009), Promising Democracy: Parties, Citizens and Election Promises. Doctoral Dissertation. Gothenburg: Department of Political Science, University of Gothenburg.

North, Douglass C., and John J. Wallis (1982), “American Government Expenditures: A Historical Perspective.” American Economic Review 72(2), 336-340.

OECD (2007), Babies and Bosses - Reconciling Work and Family Life: A Synthesis of Findings for OECD Countries. Paris: OECD.

Oxley, Les (1994), “Cointegration, Causality and Wagner's Law: A Test for Britain 1870-1913.” Scottish Journal of Political Economy 41(3), 286-298.

Palme, Joakim (2005), "Features of the Swedish Pension Reform.” Japanese Journal of Social Security Policy 4(1), 42-53.

Peacock, Alan T., and Jack Wiseman (1961), The Growth of Public Expenditure in the United Kingdom. Princeton: Princeton University Press.

Ram, Rati (1987), "Wagner's Hypothesis in Time-Series and Cross-Section Perspectives: Evidence from 'Real' Data for 115 Countries." Review of Economics and Statistics 62(2), 194-204.

Ram, Rati (2009), “Openness, Country Size, and Government Size: Additional Evidence from a Large CrossCountry Panel.” Journal of Public Economics 93(1-2), 213-218.

Ravn, Morten O., and Harald Uhlig (2002), "On Adjusting the Hodrick-Prescott Filter for the Frequency of Observations." Review of Economics and Statistics 84(2), 371-376.

Rodrik, Dani (1998), Why Do more Open Economies have Bigger Governments?” Journal of Political Economy 106(5), 997-1032.

Royed, Terry (1996), "Testing the Mandate Model in Britain and the United States: Evidence from the Reagan and Thatcher Eras." British Journal of Political Science 26(1), 45-80.

Santos, Carlos (2008), “Impulse Saturation Break Tests.” Economics Letters 98(2), 136-143.

Shelton, Cameron A. (2007), "The Size and Composition of Government Expenditure." Journal of Public Economics 91(11-12), 2230-2260.

Sinn, Hans-Werner (1998), "European Integration and the Future of the Welfare State." Swedish Economic Policy Review 5(1), 113-132.

Statistiska Centralbyrån (1969), Historisk statistik för Sverige. Del 1. Befolkning 1720-1967. Stockholm. Allmänna Förlaget.

Talvi, Ernesto, and Carlos Végh (2005), “Tax Base Variability and Procyclical Fiscal Policy in Developing Countries.” Journal of Development Economics 78(1), 156-190.

Tarschys, Daniel (1975), "The Growth of Public Expenditures - Nine Modes of Explanation.” Scandinavian Political Studies 10(1), 9-32.

Thomsson, Kaj (2010), "Public and Private Welfare State Institutions: A Formal Theory of American Exceptionalism.” IFN Working Paper No. 822. Stockholm: Research Institute of Industrial Economics.

Tussing, A. Dale, and John A. Henning (1979), "Econometric Testing of the Displacement Effect: A Comment" Finanzarchiv, 37(3), 477-484.

Wagner, Adolph (1883), Finanzwissenschaft, 3rd ed., Leipzig. Partly reprinted in Richard A. Musgrave and Alan T. Peacock, eds. (1958), Classics in the Theory of Public Finance. London: Macmillan.

Wagner, Adolph (1893), Grundlegung der politischen Ökonomie, 3rd ed. Leipzig.

Wagner, Adolph (1911), ’Der Staat in nationalökonomischer Hinsicht.”, In Johannes Conrad et al., eds., Handwörterbuch der Staatswissenschaften, $3^{\text {rd }}$ completely revised ed., Vol. 7. Jena: G. Fisher.

Wagner, Richard E., and Warren E. Weber (1977), "Wagner's Law, Fiscal Institutions, and the Growth of Government.” National Tax Journal 30(1), 59-68.

Wiseman, Jack, and Jack Diamond (1975), "Comment on Long-run Growth of Nondefense Government Expenditures in the United States.” Public Finance Quarterly 3(4), 411-414.

Zaghini, Andrea, and Serena Lamartina (2008), "Increasing Public Expenditures: Wagner's Law in OECD Countries." CFS Working Paper No. 2008/13, Center for Financial Studies, University of Frankfurt.

Ziramba, Emmanuel (2008), "Wagner's Law: An Econometric Test for South Africa, 1960-2006." South African Journal of Economics 76(4), 596-606. 
Figure 1. Government expenditure as a share of GDP in Sweden, 1800-1913, and the UK, $1830-1913$

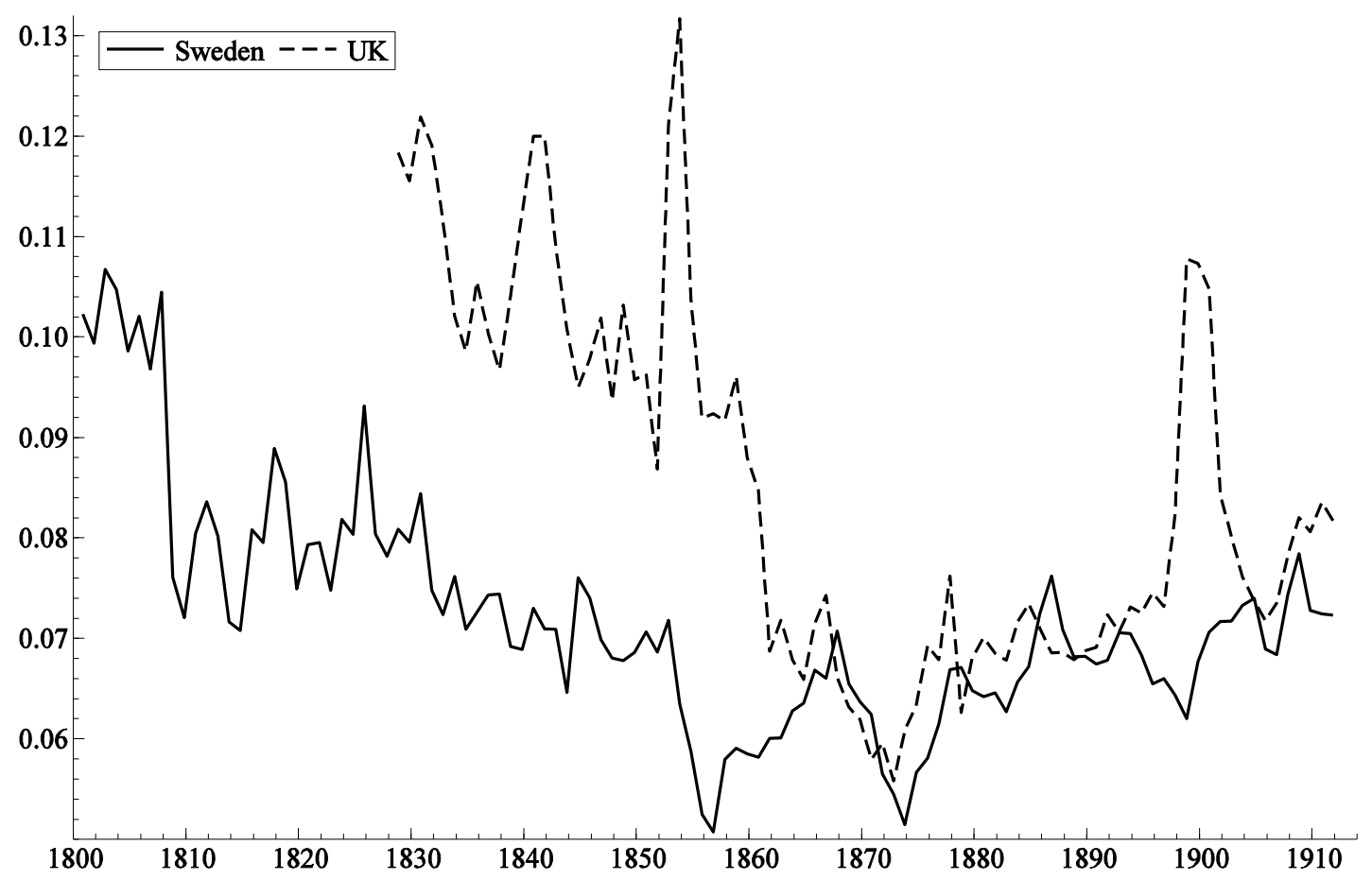

Figure 2. Government expenditure as a share of GDP in Sweden and the UK, 1920-2006

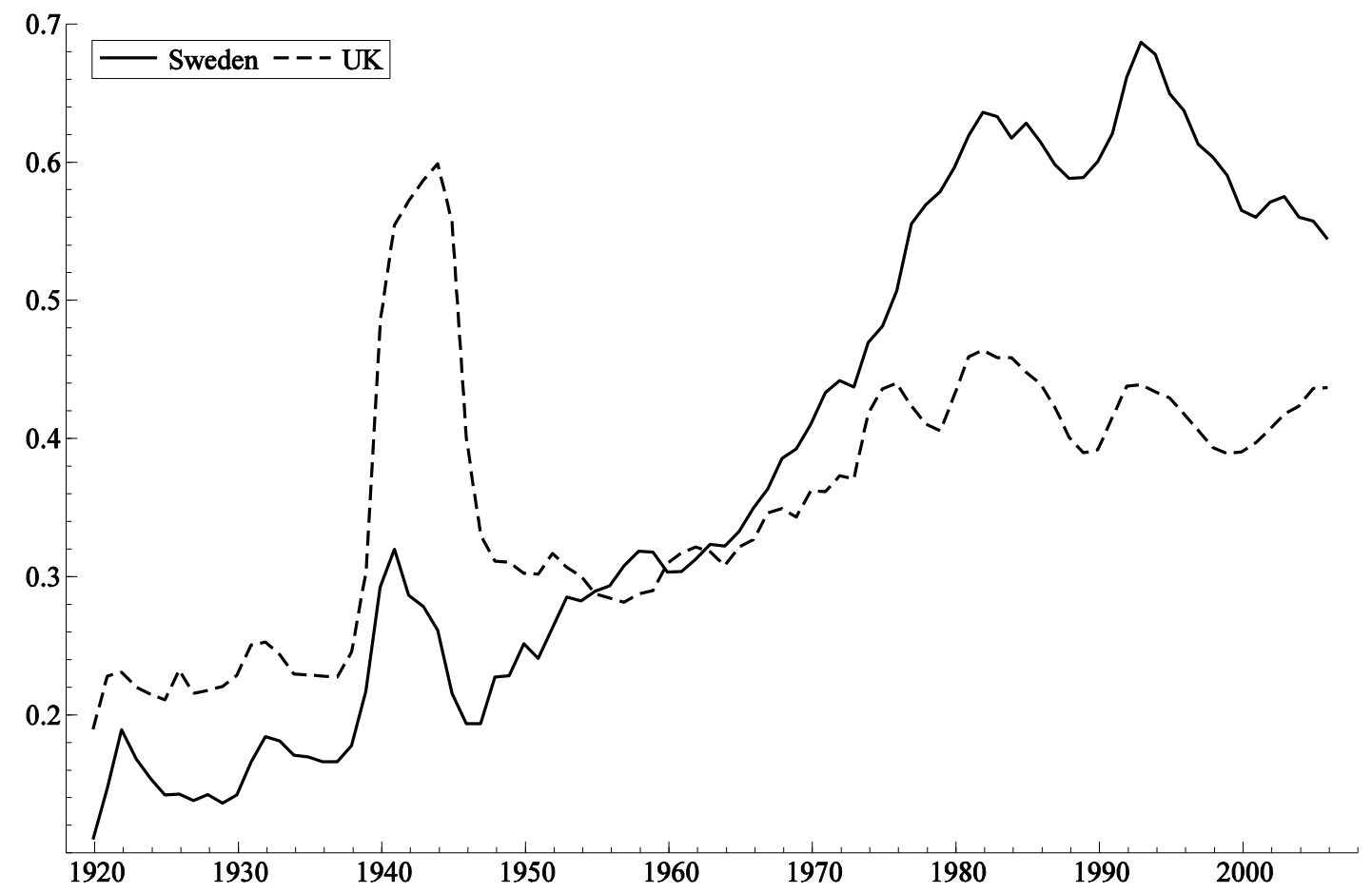


Figure 3. Government expenditure as a share of GDP and real GDP per capita in Sweden, 1800-1913 (in logs)

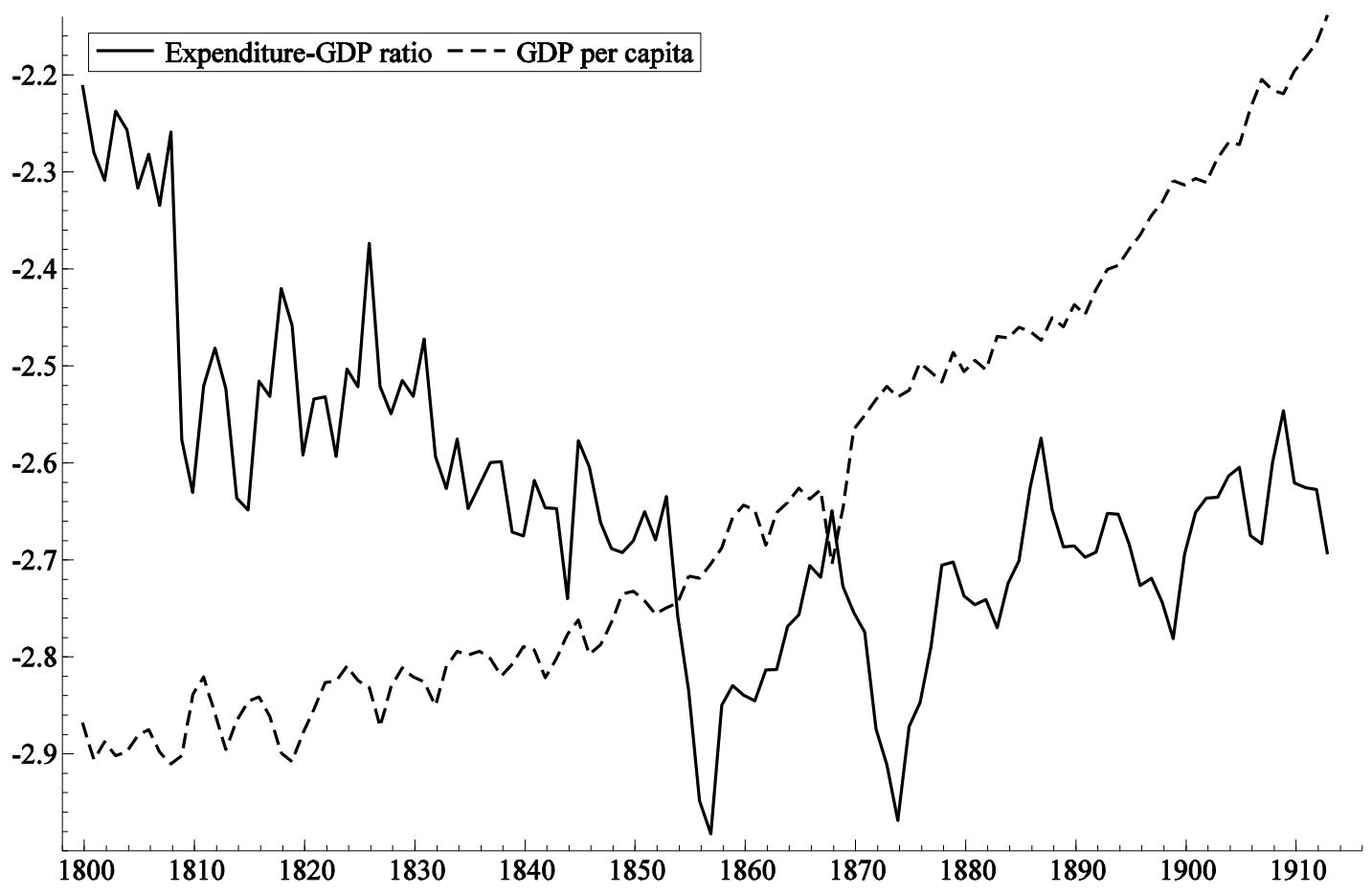

Note: GDP per capita has been mean and variance adjusted.

Figure 4. Government expenditure as a share of GDP and real GDP per capita in Sweden, 1870-1913 (in logs)

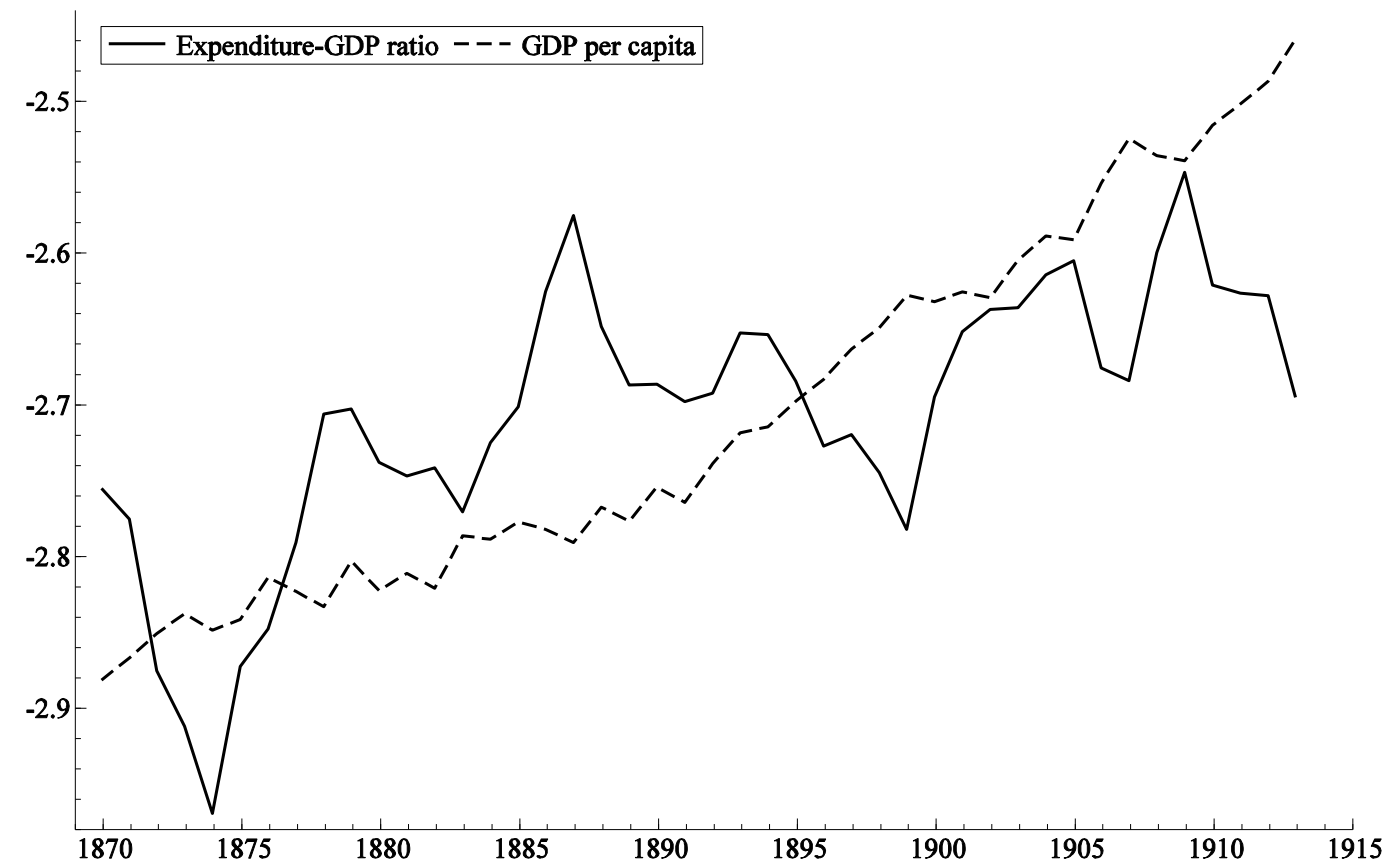

Note: GDP per capita has been mean and variance adjusted. 
Figure 5. Government expenditure as a share of in GDP and real GDP per capita in the UK, 1830-1913 (in logs)

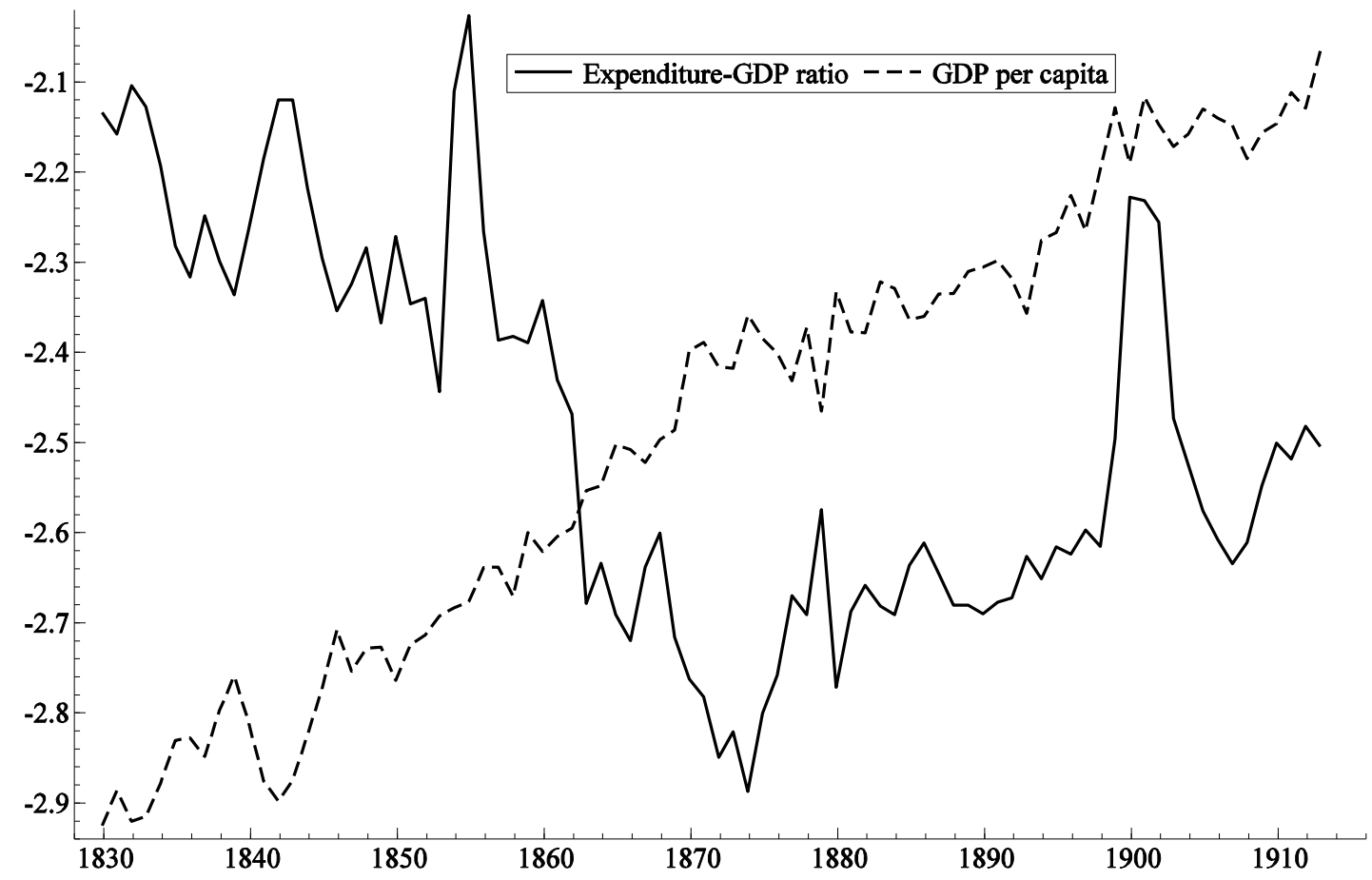

Note: GDP per capita has been mean and variance adjusted.

Figure 6. Government expenditure as a share of in GDP and real GDP per capita in the UK, 1870-1913 (in logs)

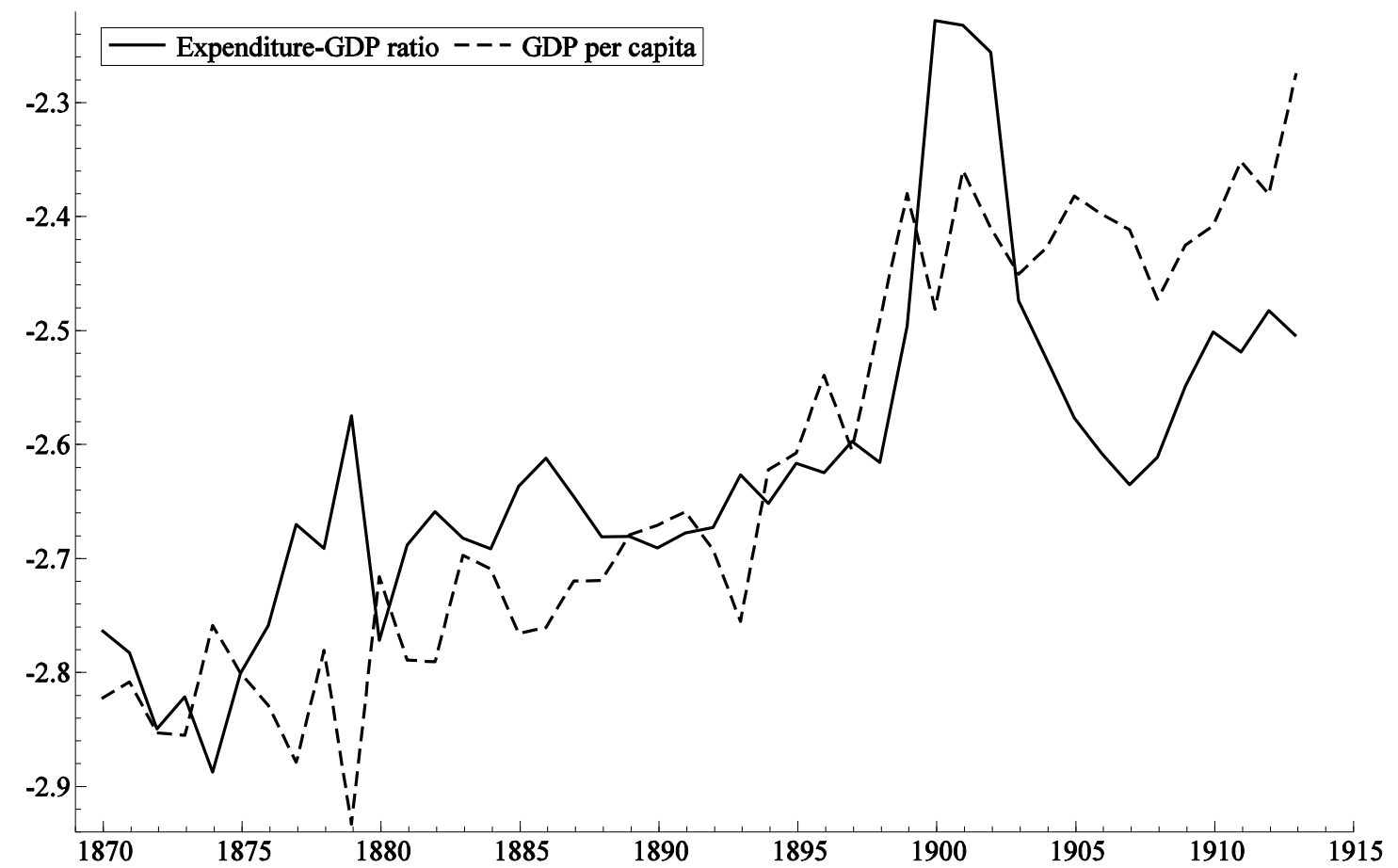

Note: GDP per capita has been mean and variance adjusted. 
Figure 7. Government expenditure as a share of in GDP and real GDP per capita in Sweden, 1920-2006 (in logs)

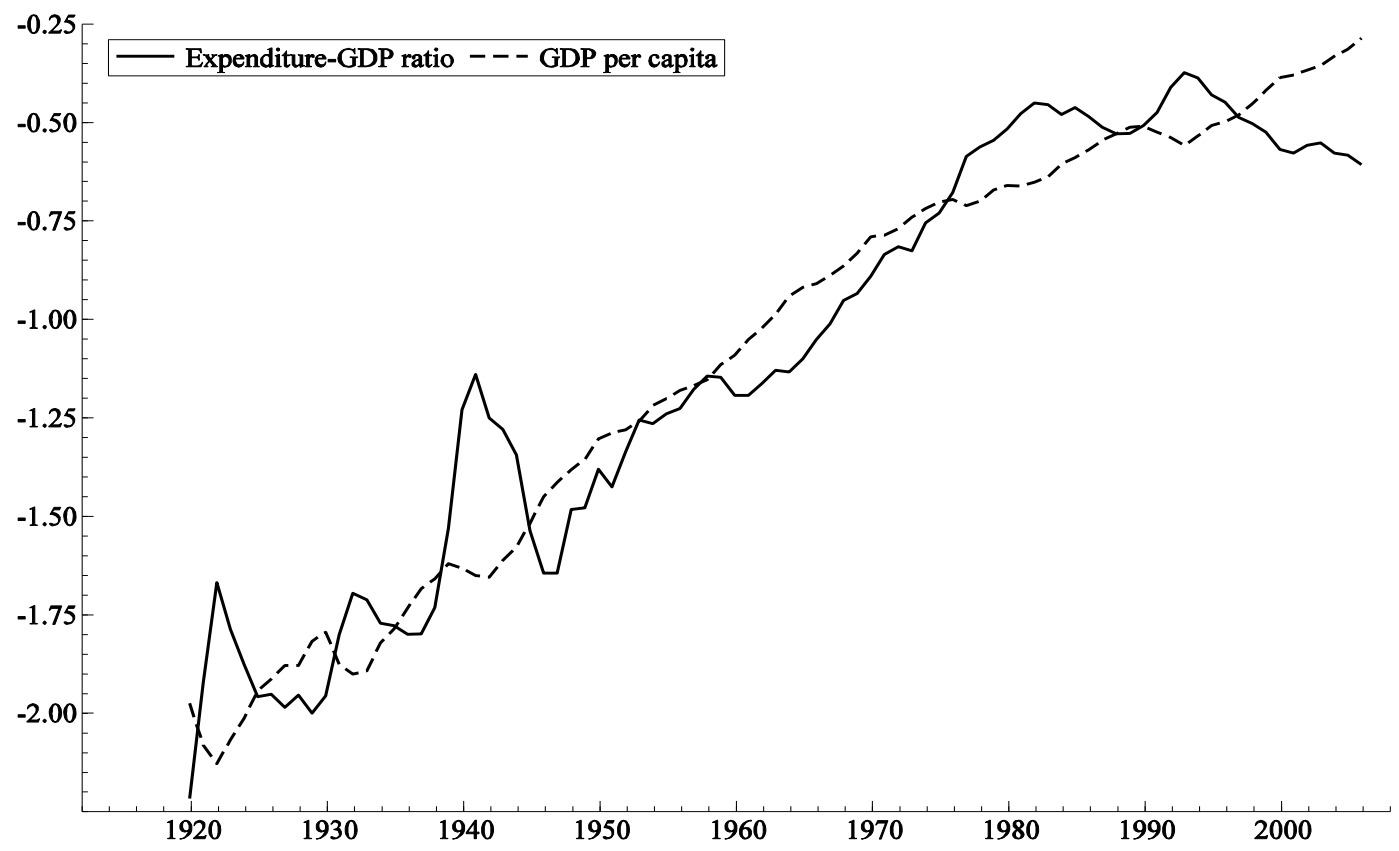

Note: GDP per capita has been mean and variance adjusted.

Figure 8. Government expenditure as a share of in GDP and real GDP per capita in the UK, 1920-2006 (in logs)

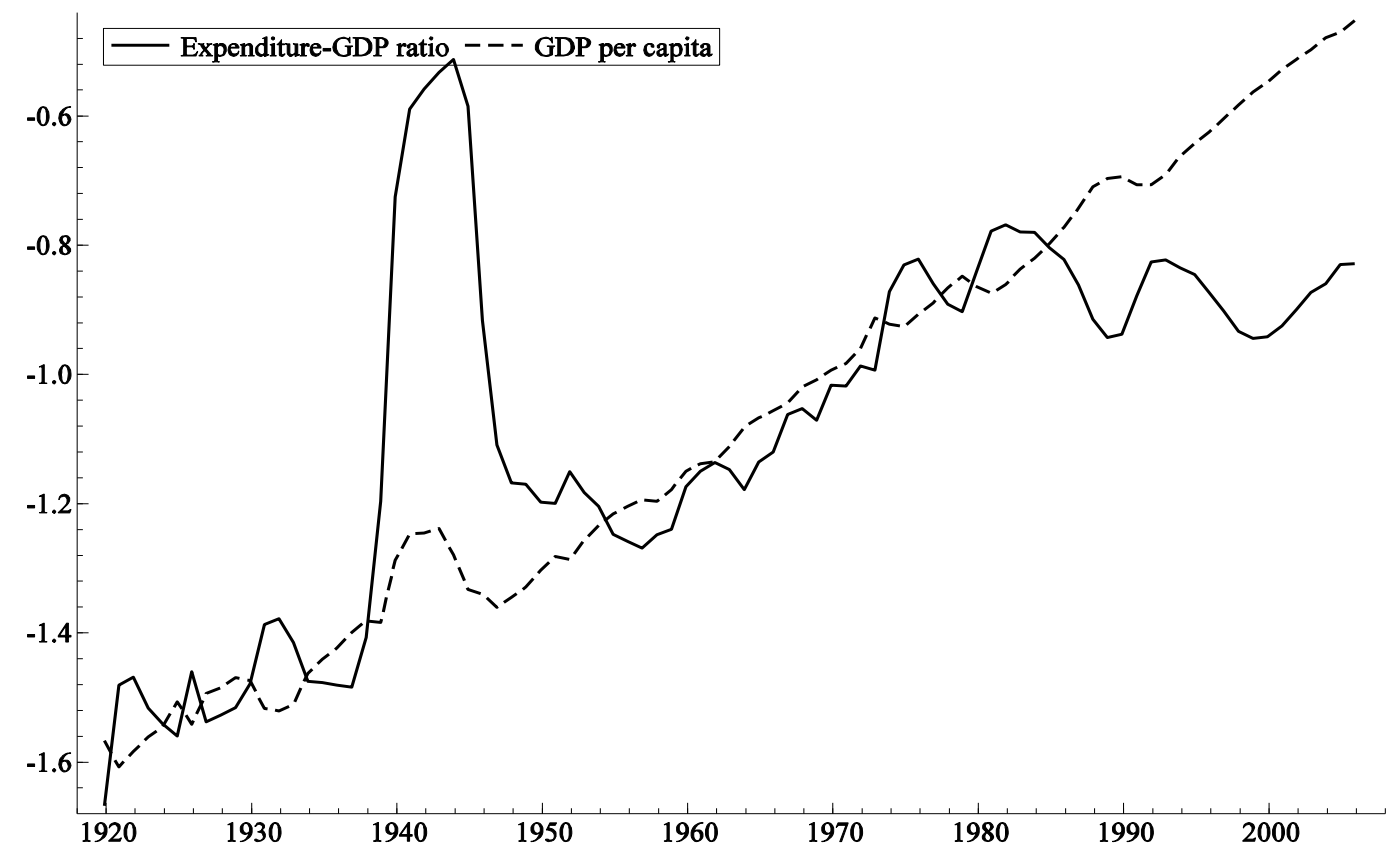

Note: GDP per capita has been mean and variance adjusted. 
Figure 9. Cointegrating vector: Sweden, 1920-2006 (upper panel, Table 1)

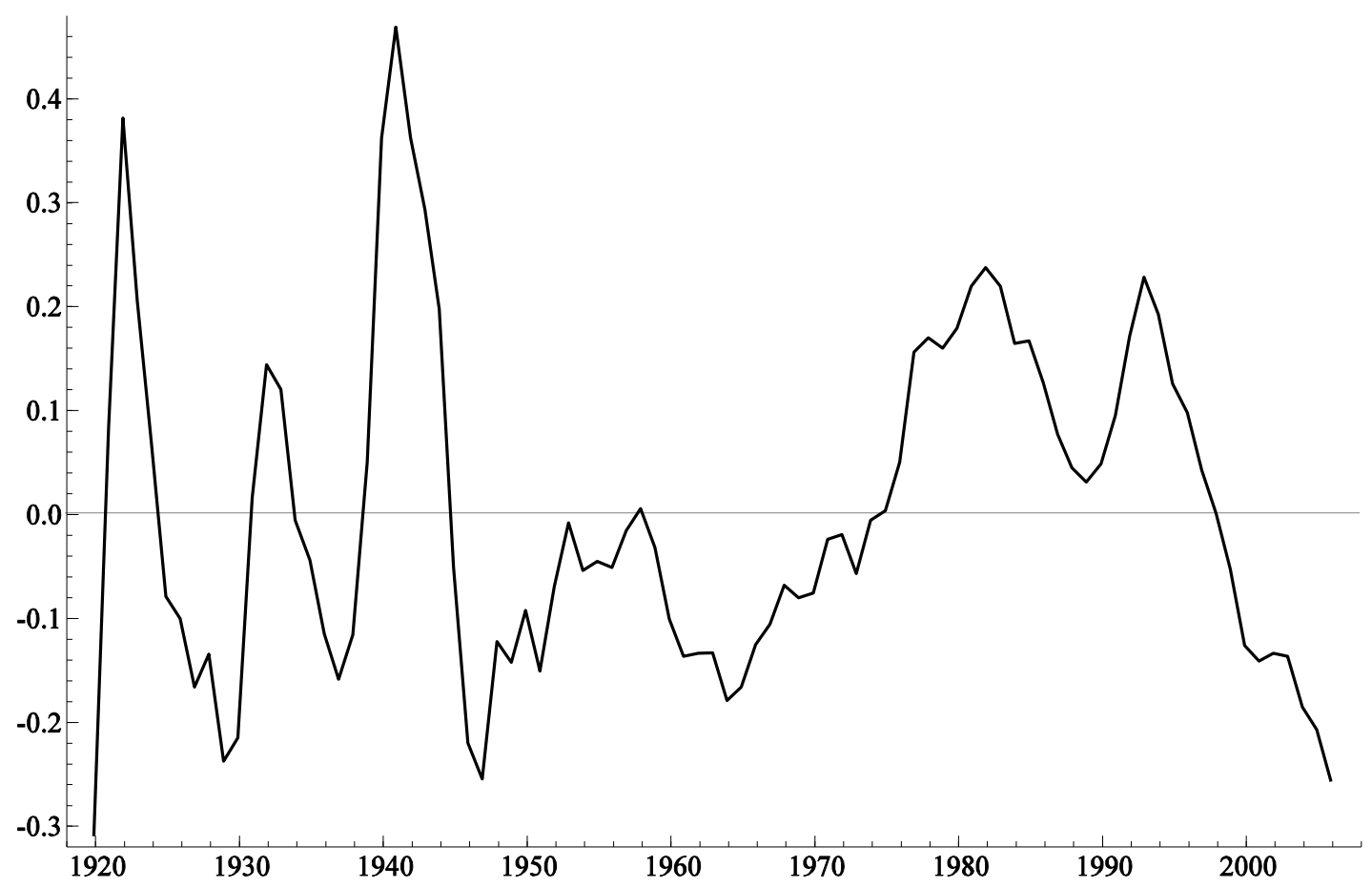

Figure 10. Cointegrating vector: the UK, 1920-2006 (upper panel Table 2)

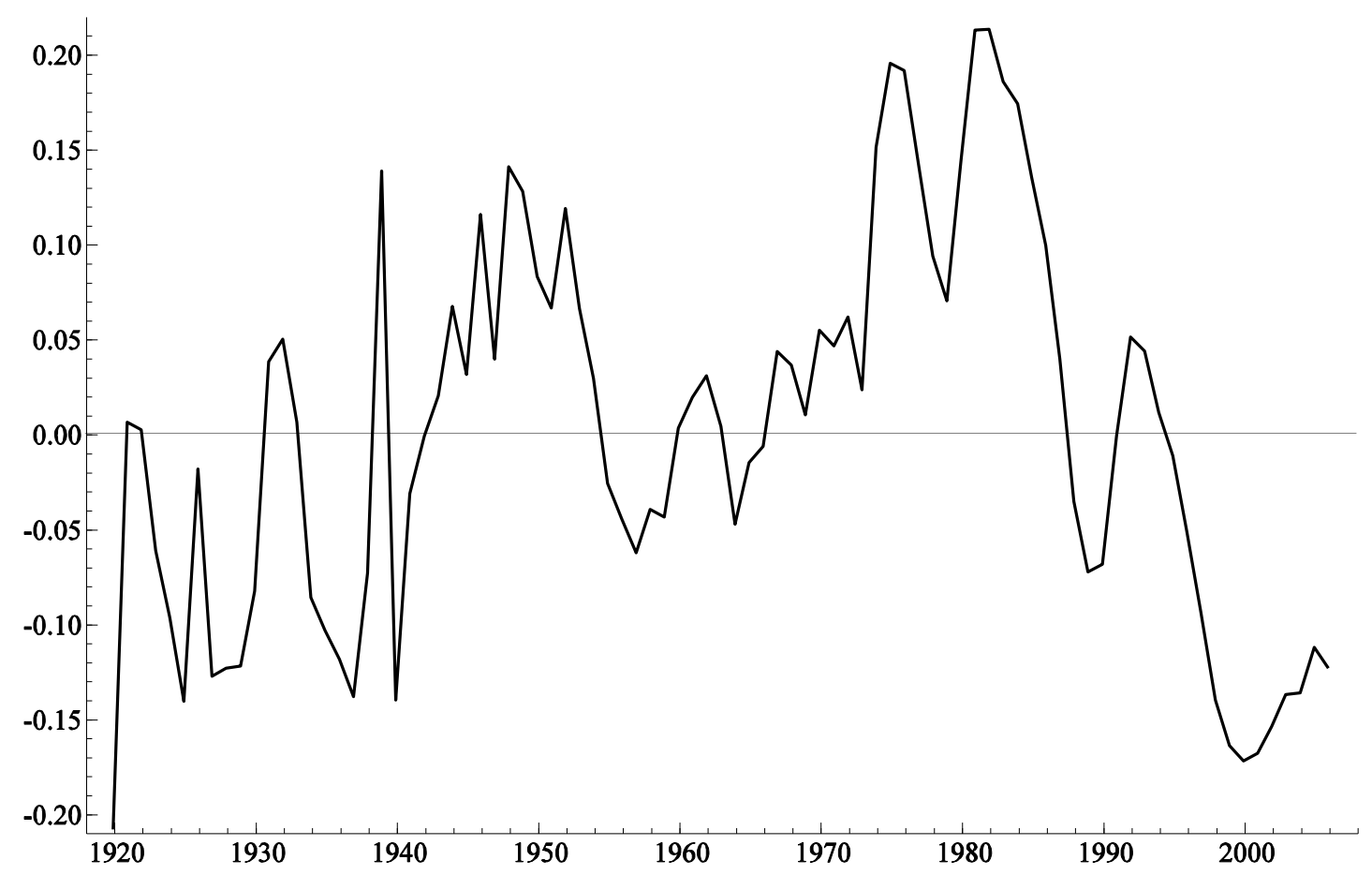


Figure 11. Cointegrating vector and dependency ratio: Sweden, 1965-2006

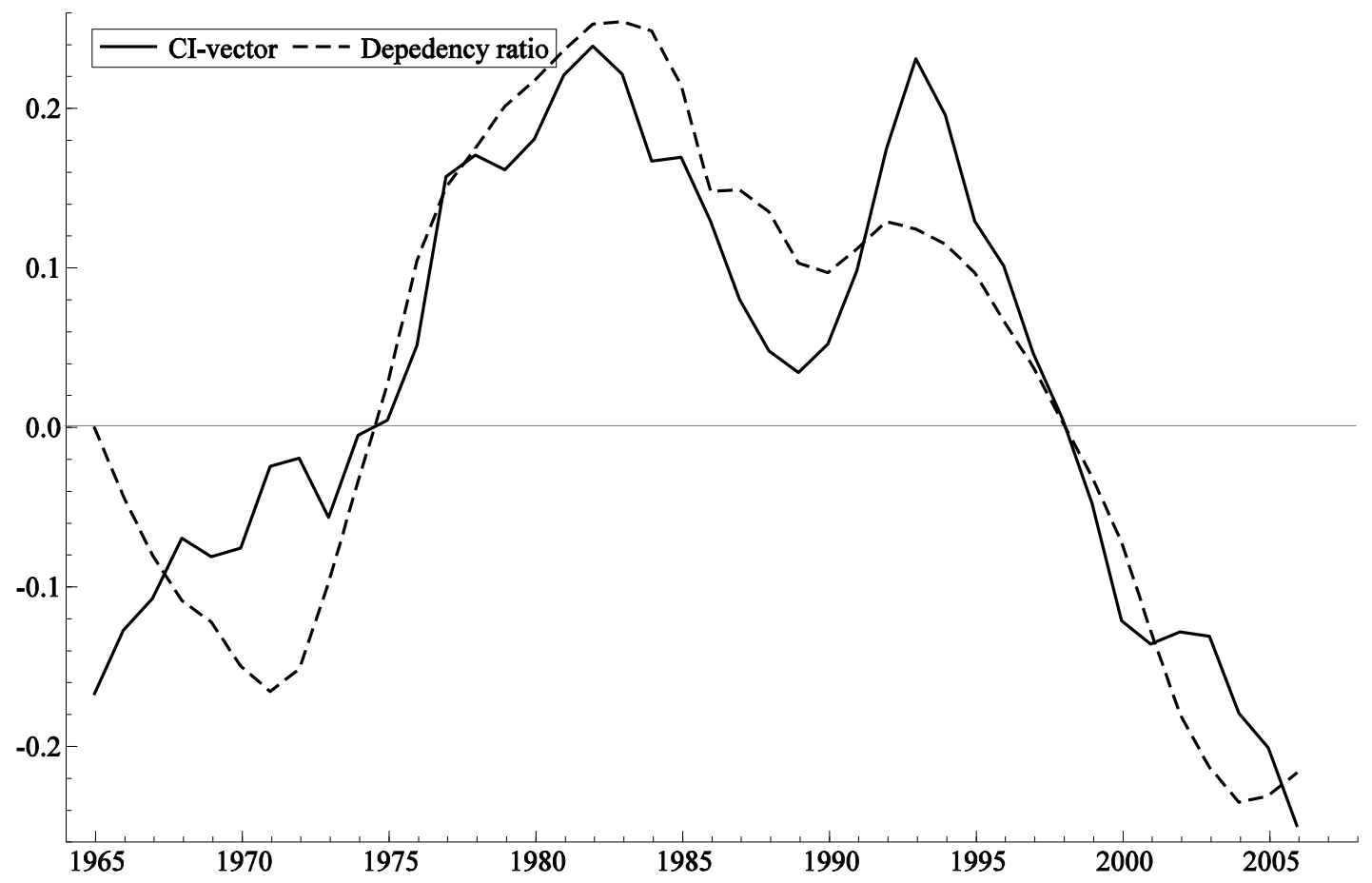

Note: The dependency ratio is variance and mean adjusted and lagged two years and the CI-vector is $g s+9.53-0.73 y p c$.

Figure 12. Cointegrating vector and dependency ratio: the UK, 1965-2006

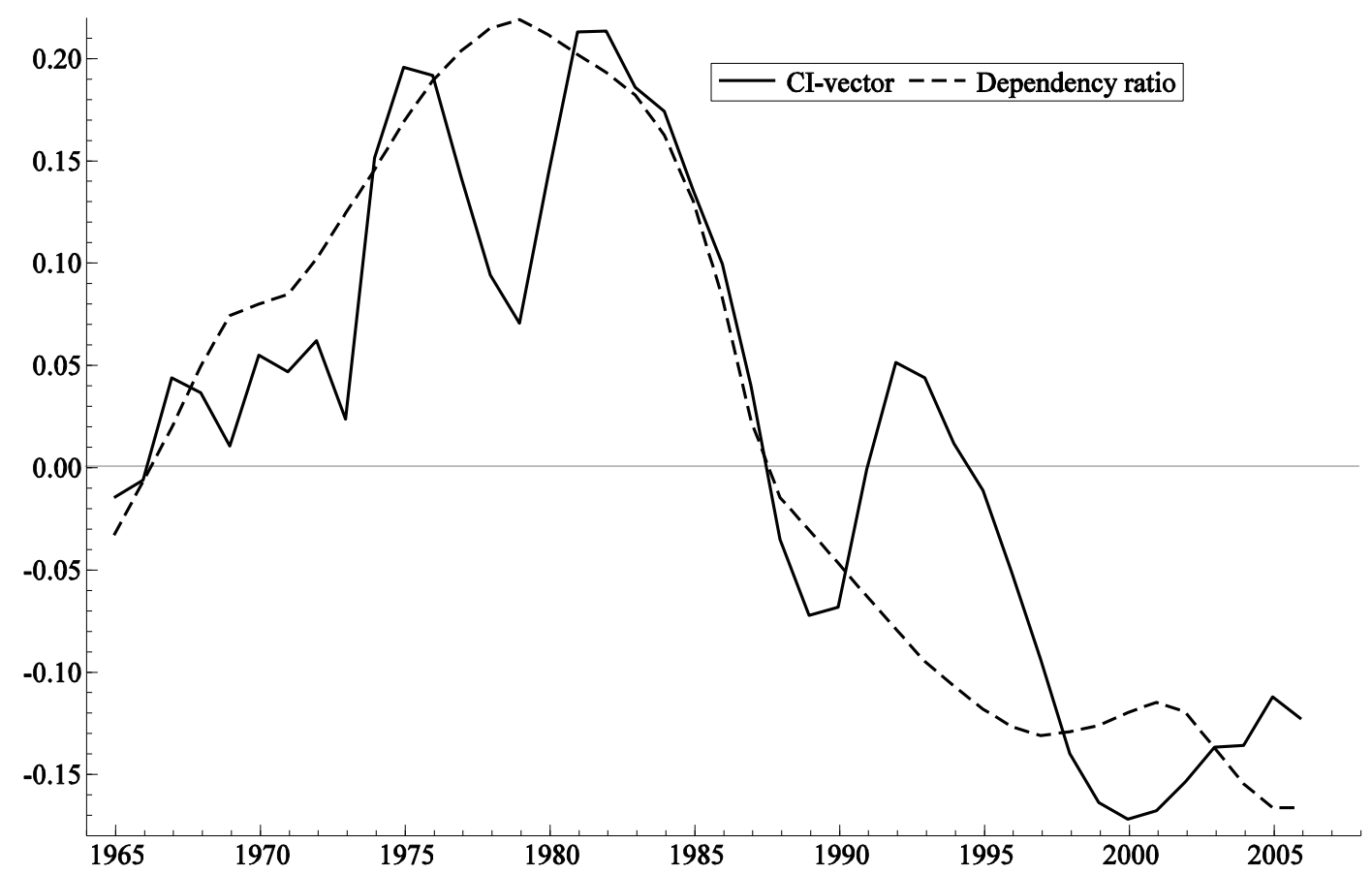

Note: The dependency ratio is variance and mean adjusted and lagged two years and the CI-vector is $g s+5.43-0.48 y p c-0.48$ wardum . 
Figure 13. Actual and peak values of $g s$ : Sweden, 1800-2006

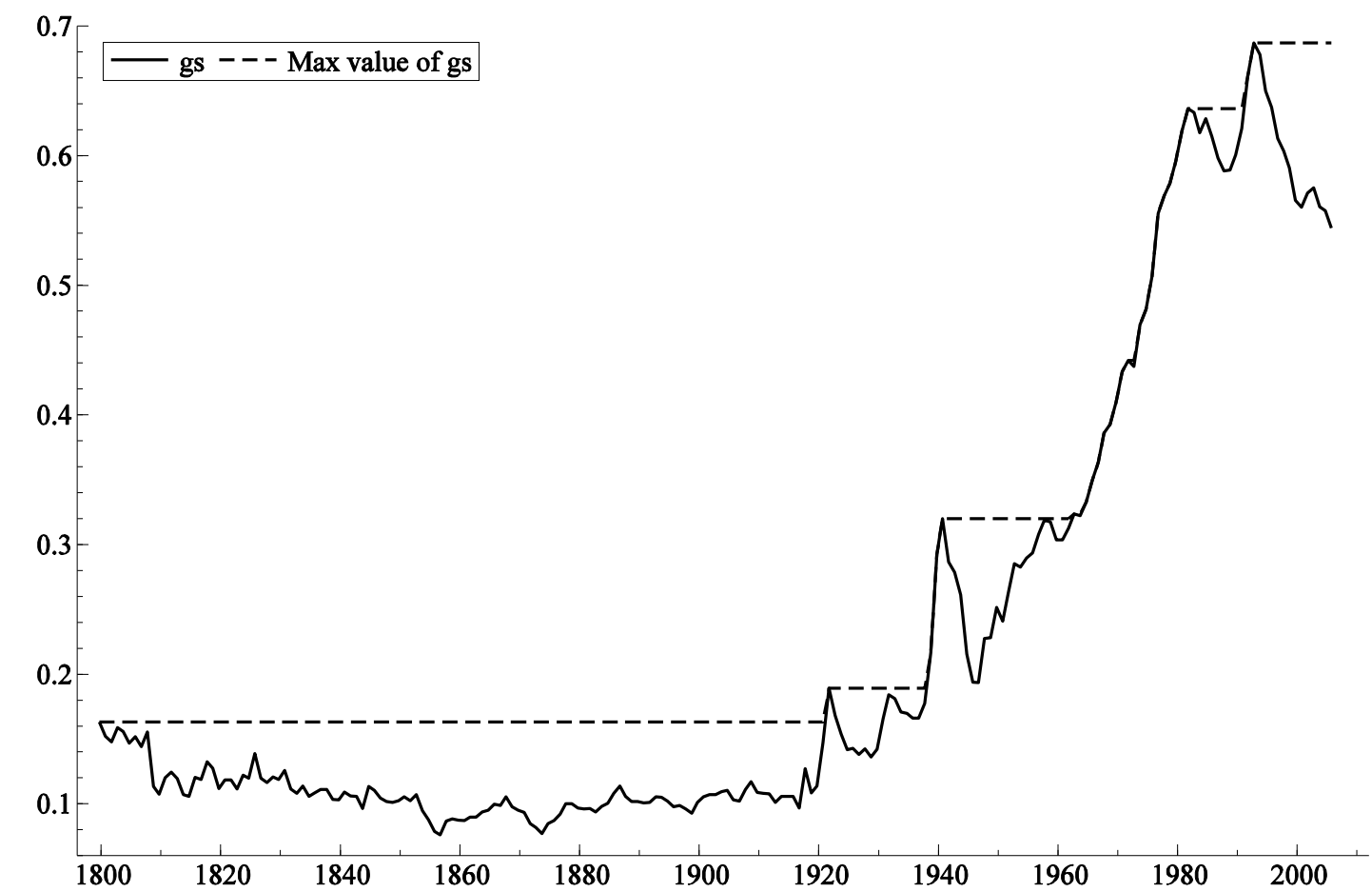

Figure 14. Actual and peak values of $g s$ : the UK, 1830-2006

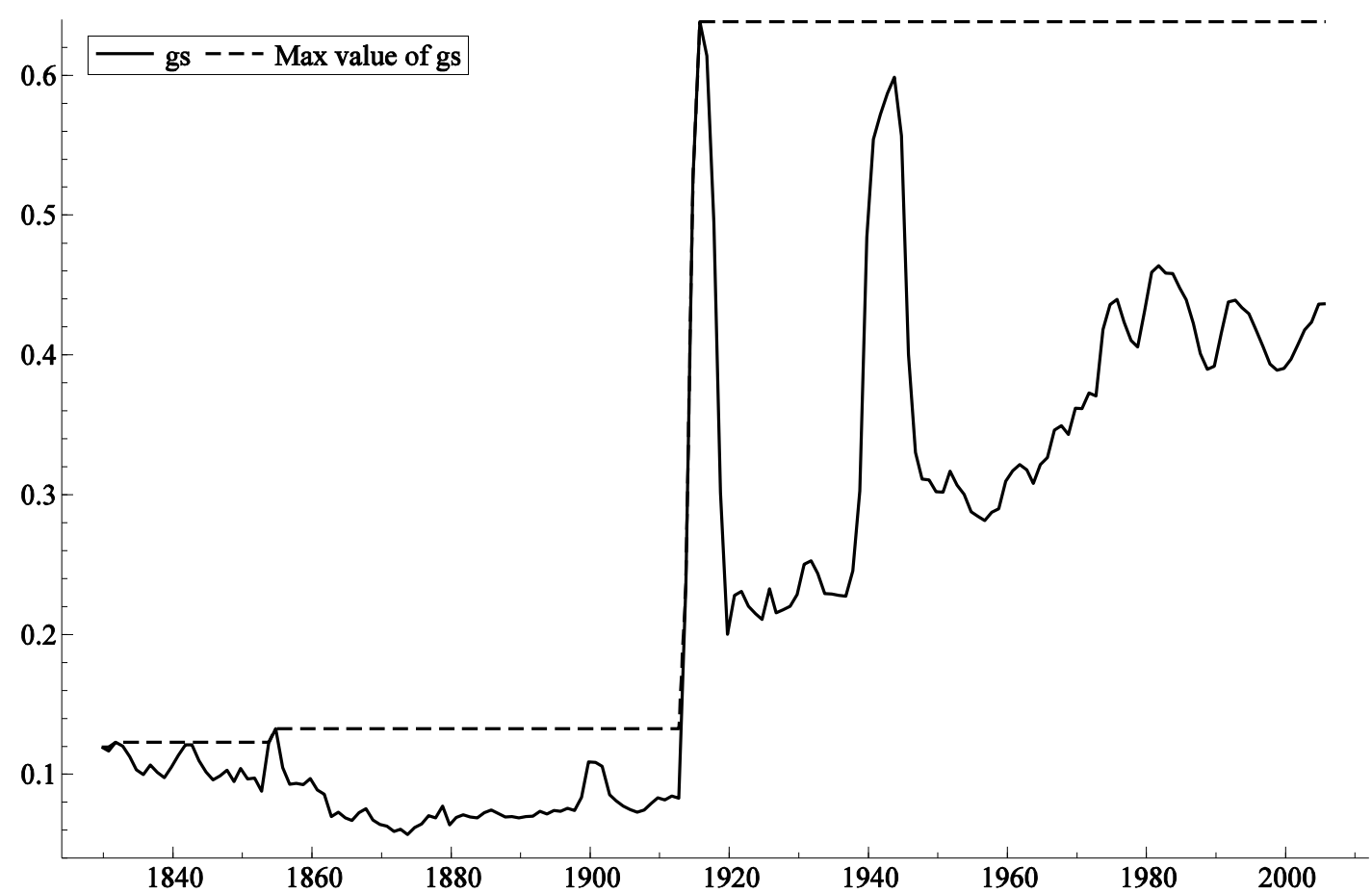


Figure 15 Actual and peak values of $g s$ : the UK, 1950-2006

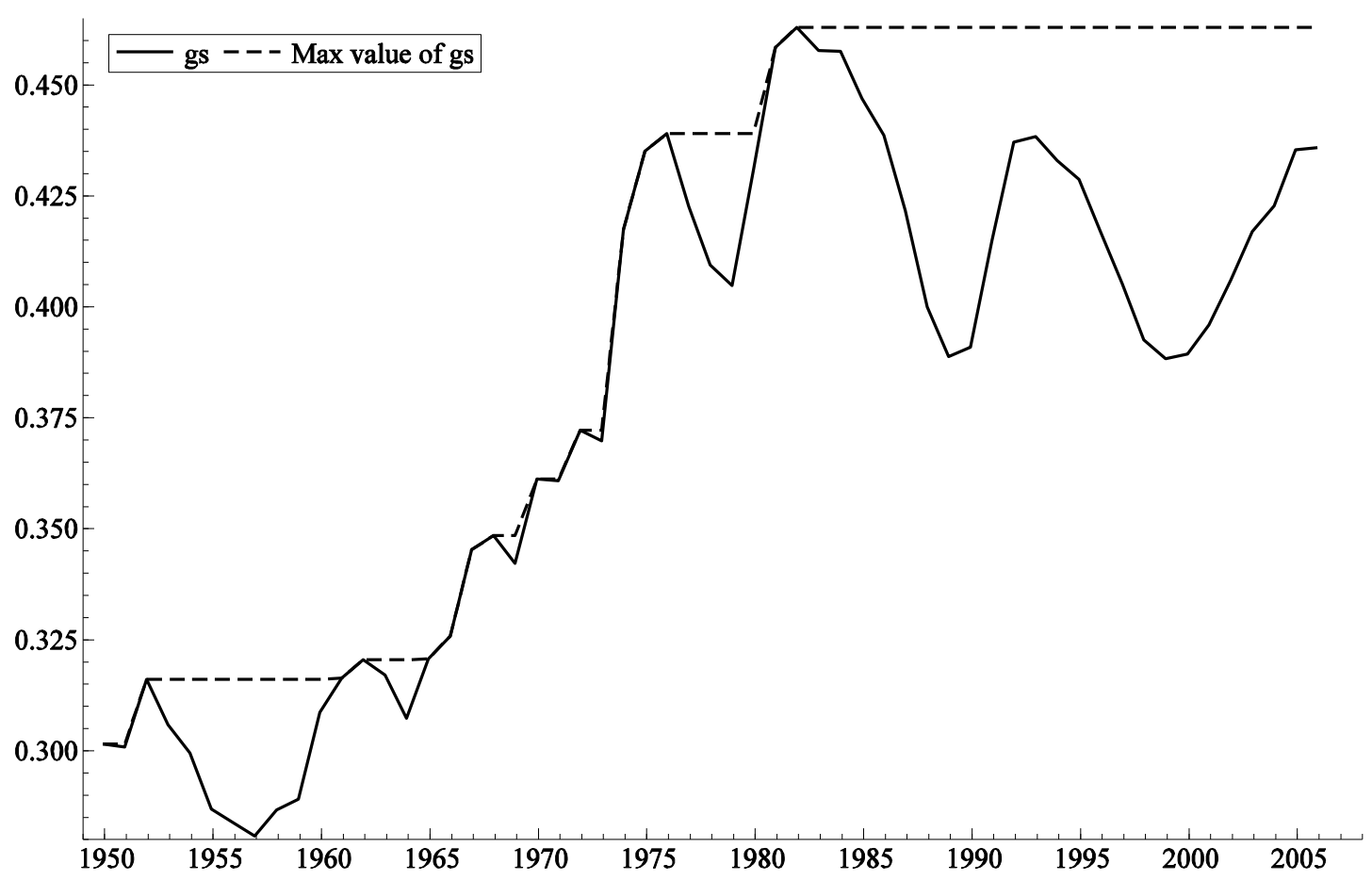


Table 1: Cointegration tests, Sweden

\begin{tabular}{lllllll}
\hline Sweden & $A D F$ & Lags & Root & $\begin{array}{l}\text { ADF* } \\
(C / S)\end{array}$ & $\begin{array}{l}\text { Break } \\
\text { date }\end{array}$ & Time period \\
\hline$g s=-1.14-0.16 y p c$ & $-3.31^{\mathrm{a}}$ & 0 & 0.86 & $-6.22^{\mathrm{c}}$ & 1860 & $1800-1913$ \\
$g s=7.95-1.15 y p c$ & $-5.12^{\mathrm{c}}$ & 0 & 0.43 & $-6.17^{\mathrm{c}}$ & 1808 & $1800-1859$ \\
$g s=-4.41+0.17 y p c$ & $-3.24^{\mathrm{a}}$ & 1 & 0.68 & -4.46 & 1880 & $1860-1913$ \\
$g s=-9.53+0.73 y p c$ & $-4.78^{\mathrm{c}}$ & 1 & 0.76 & $-6.04^{\mathrm{c}}$ & 1974 & $1920-2006$ \\
$g s=-8.49+0.64 y p c$ & $-5.02^{\mathrm{c}}$ & 1 & 0.64 & $-5.53^{\mathrm{b}}$ & 1947 & $1920-1973$ \\
$g s=-1.02-0.04 y p c$ & -2.88 & 1 & 0.84 & -4.54 & 1997 & $1974-2006$ \\
$g s=-8.21+0.61 y p c$ & $-4.50^{\mathrm{c}}$ & 1 & 0.64 & $-5.27^{\mathrm{b}}$ & 1947 & $1920-1964$ \\
$g s=-8.33+0.63 y p c$ & -1.24 & 1 & 0.95 & -4.39 & 1979 & $1965-2006$ \\
& With dependency ratio & & & & \\
$g s=-2.55-0.10 y p c-2.55 \mathrm{dep}$ & $-5.11^{\mathrm{c}}$ & 0 & 0.43 & $-6.24^{\mathrm{c}}$ & 1808 & $1800-1859$ \\
$g s=7.20-1.13 y p c-0.14 \mathrm{dep}$ & -3.30 & 1 & 0.67 & -4.61 & 1875 & $1860-1913$ \\
$g s=-3.92+0.15 y p c+0.35 \mathrm{dep}$ & $-6.25^{\mathrm{c}}$ & 1 & 0.66 & $-7.10^{\mathrm{c}}$ & 1974 & $1920-2006$ \\
$g s=-9.51+0.73 y p c+8.36 i d e p$ & $-3.76^{\mathrm{a}}$ & 1 & 0.60 & -4.42 & 1979 & $1965-2006$ \\
$g s=-6.03+0.73 y p c+6.03 \mathrm{dep}$ & -3.38 & 1 & 0.66 & -4.47 & 1996 & $1974-2006$ \\
$g s=-8.72+0.67 y p c+8.36 \mathrm{dep}$ & & & & & & \\
\hline
\end{tabular}

Note: $A D F$ is the Engle-Granger cointegration test and $A D F^{*}$ is the Gregory-Hansen cointegration test allowing for a regime shift $(\mathrm{C} / \mathrm{S})$. Significance levels are indicated by letters; $10 \%=\mathrm{a}, 5 \%=\mathrm{b}$, and $1 \%=\mathrm{c}$. The variables are defined as follows: $g s$ is the log of government expenditure as a share of GDP, $y p c$ is the log of per capita real GDP, dep is the dependency ratio, measured as those aged $0-14$ and $65+$ divided by those $15-64$, for the period 1800-1913, and those aged 0-19 and 65+ divided by those 20-64 for 1920-2006. idep is dep demeaned. The second lag of dep and idep is used. 
Table 2: Cointegration tests, UK 1830-2006

\begin{tabular}{lcccccc}
\hline United Kingdom & $A D F$ & Lags & Root & $\begin{array}{l}A D F^{*} \\
(C / S)\end{array}$ & $\begin{array}{l}\text { Break } \\
\text { date }\end{array}$ & Time period \\
\hline$g s=-0.03-0.67 y p c$ & -2.10 & 0 & 0.89 & $-5.15^{\mathrm{b}}$ & 1864 & $1830-1913$ \\
$g s=-1.06-1.36 y p c$ & $-3.30^{\mathrm{a}}$ & 1 & 0.47 & $-5.01^{\mathrm{b}}$ & 1853 & $1830-1863$ \\
$g s=-5.67+0.80 y p c$ & $-3.56^{\mathrm{b}}$ & 0 & 0.61 & $-5.58^{\mathrm{c}}$ & 1904 & $1864-1913$ \\
$g s=-0.43-0.57 y p c$ & -2.41 & 1 & 0.86 & -3.93 & 1897 & $1841-1913$ \\
$g s=-5.43+0.48 y p c$ & -1.37 & 1 & 0.92 & -3.13 & 1949 & $1920-2006$ \\
$g s=-5.41+0.48 y p c+0.98 w d$ & -3.18 & 0 & 0.81 & $-5.28^{\mathrm{a}}$ & 1973 & $1920-2006$ \\
$g s=-6.41+0.59 y p c+0.99 w d$ & $-4.36^{\mathrm{b}}$ & 0 & 0.50 & $-5.24^{\mathrm{a}}$ & 1938 & $1920-1972$ \\
$g s=-0.16-0.07 y p c$ & -3.16 & 1 & 0.67 & -4.03 & 1999 & $1973-2006$ \\
$g s=-6.53+0.61 y p c+0.98 w d$ & $-3.94^{\mathrm{b}}$ & 0 & 0.50 & $-5.47^{\mathrm{c}}$ & 1938 & $1920-1964$ \\
$g s=-2.45+0.16 y p c$ & -2.81 & 1 & 0.82 & $-5.19^{\mathrm{b}}$ & 1985 & $1965-2006$ \\
& With dependency ratio & & & & \\
$g s=-2.07-1.17 y p c-4.15 d e p$ & $-3.96^{\mathrm{b}}$ & 1 & 0.68 & $-5.25^{\mathrm{a}}$ & 1880 & $1841-1913$ \\
$g s=-6.10+0.56 y p c+0.99 w d+2.30 i d e p$ & $-5.03^{\mathrm{c}}$ & 0 & 0.58 & $-5.18^{\mathrm{c}}$ & 1941 & $1920-2006$ \\
$g s=-5.47+0.49 y p c+2.04 d e p$ & $-3.97^{\mathrm{b}}$ & 1 & 0.59 & $-5.31^{\mathrm{b}}$ & 1996 & $1965-2006$ \\
$g s=-1.64+0.11 y p c+0.72 d e p$ & $-4.29^{\mathrm{b}}$ & 1 & 0.65 & -5.39 & 1994 & $1973-2006$ \\
\hline
\end{tabular}

Note: $A D F$ is the Engle-Granger cointegration test and $A D F^{*}$ is the Gregory-Hansen cointegration test allowing for a regime shift (C/S). Significance levels are indicated by letters; $10 \%=\mathrm{a}, 5 \%=\mathrm{b}$, and $1 \%=\mathrm{c}$. The variables are defined as follows: $g s$ is the log of government expenditure as a share of GDP, $y p c$ is the log of per capita real GDP, dep is the dependency ratio, measured as those aged 0-14 and 65+ divided by those 15-64, for the period 1800-1913, and those aged 0-19 and 65+ divided by those 20-64 for 1920-2006. idep is dep demeaned, and odep and ydep are the dependency ratio for old and young, respectively. The third lag of dep is used. wd is the war dummy based on estimates with Autometrics. For 1940 to 1946 it is $0.56,0.66,0.72,0.77,0.73,0.46$, and zero otherwise. 
Table 3: Test of asymmetric response, Sweden

\begin{tabular}{ccccccccccc}
\hline & \multicolumn{3}{c}{ Coefficients $b_{i j}$} & \multicolumn{3}{c}{ Steady-state coefficients $\beta_{j}$} & \multicolumn{2}{c}{ Test of asymmetry } \\
& \multicolumn{2}{c}{ Good times } & \multicolumn{2}{c}{ Bad times } & Good & Bad & Diff. & \multicolumn{2}{c}{$\chi^{2}(1)$} \\
Time period & \multicolumn{1}{c}{$b_{1 P}$} & $b_{2 P}$ & $b_{1 N}$ & $b_{2 N}$ & $\beta_{P}$ & $\beta_{N}$ & $\beta_{P}-\beta_{N}$ & $\beta_{P}-\beta_{N}=0$ & $b_{2 P}-b_{2 N}=0$ \\
& & & & & & & & & \\
\hline $1803-1913$ & 0.051 & 0.363 & 0.079 & $0.916^{\mathrm{c}}$ & 0.348 & $0.835^{\mathrm{b}}$ & -0.49 & 1.32 & 0.89 \\
& $(0.12)$ & $(0.89)$ & $(0.26)$ & $(3.00)$ & $(0.76)$ & $(2.22)$ & & {$[0.25]$} & {$[0.34]$} \\
$1803-1859$ & 0.306 & 0.699 & 0.409 & $1.487^{\mathrm{b}}$ & 0.799 & $1.506^{\mathrm{a}}$ & -0.71 & 0.37 & 0.65 \\
& $(0.44)$ & $(1.07)$ & $(0.72)$ & $(2.57)$ & $(1.07)$ & $(1.97)$ & & {$[0.54]$} & {$[0.42]$} \\
$1860-1913$ & -0.663 & 0.178 & -0.276 & $0.764^{\mathrm{b}}$ & -0.562 & 0.566 & -1.13 & 1.53 & 0.79 \\
& $(-1.38)$ & $(0.37)$ & $(-0.91)$ & $(2.53)$ & $(-0.82)$ & $(1.19)$ & & {$[0.22]$} & {$[0.37]$} \\
$1923-2006$ & -0.624 & $1.459^{\mathrm{c}}$ & $-1.360^{\mathrm{b}}$ & $2.231^{\mathrm{c}}$ & 1.158 & 1.207 & -0.05 & 0.00 & 1.32 \\
& $(-1.46)$ & $(3.44)$ & $(-2.60)$ & $(5.36)$ & $(1.64)$ & $(1.61)$ & & {$[0.96]$} & {$[0.25]$} \\
$1923-1936$ & -0.365 & $1.165^{\mathrm{b}}$ & $-2.083^{\mathrm{c}}$ & 1.627 & 1.316 & -0.464 & 1.78 & 0.75 & 0.00 \\
& $(-0.59)$ & $(2.73)$ & $(-2.31)$ & $(1.62)$ & $(1.64)$ & $(-0.33)$ & & {$[0.38]$} & {$[0.98]$} \\
$1952-2006$ & -0.850 & $1.52^{\mathrm{b}}$ & $-1.301^{\mathrm{b}}$ & $2.124^{\mathrm{c}}$ & 1.831 & 2.218 & -0.39 & 1.50 & 0.24 \\
& $(-1.20)$ & $(2.21)$ & $(-1.80)$ & $(2.87)$ & $(0.75)$ & $(0.62)$ & & {$[0.47]$} & {$[0.63]$} \\
\hline
\end{tabular}

Notes: $t$-values in parentheses. The letters indicate significance at $10 \%=\mathrm{a}, 5 \%=\mathrm{b}$, and $1 \%=\mathrm{c}$. The coefficients and standard errors reported are from the solved static state of Eq. (4). All models are estimated with two lags of the dependent variable. The regressions have war impulse dummies in 1809 and 1939, 1940, 1942 and 1945.

Detailed regression results are available on request. The de-trending of GDP per capita was done with the Hodrick-Prescott filter. The adjustment parameter was set to 6.25 , following the recommendation of Ravn and Uhlig (2002). 
Table 4: Test of asymmetric response, United Kingdom

\begin{tabular}{ccccccccccc}
\hline & \multicolumn{3}{c}{ Coefficients $b_{i j}$} & \multicolumn{3}{c}{ Steady state coefficients $\beta_{j}$} & \multicolumn{2}{c}{ Tests of asymmetry } \\
& \multicolumn{2}{c}{ Good times } & \multicolumn{2}{c}{ Bad times } & Good & Bad & Diff. & \multicolumn{2}{c}{$\chi^{2}(1)$} \\
Time period & $b_{1 P}$ & $b_{2 P}$ & $b_{1 N}$ & $b_{2 N}$ & $\beta_{P}$ & $\beta_{N}$ & $\beta_{P}-\beta_{N}$ & $\beta_{P}-\beta_{N}=0$ & $b_{2 P}-b_{2 N}=0$ \\
& & & & & & & & & \\
\hline $1833-1913$ & -0.338 & $2.130^{\mathrm{c}}$ & $-2.012^{\mathrm{c}}$ & $1.374^{\mathrm{a}}$ & $2.389^{\mathrm{a}}$ & -0.851 & 3.24 & 2.30 & 0.41 \\
& $(-0.48)$ & $(3.03)$ & $(-3.02)$ & $(1.95)$ & $(1.75)$ & $(-0.67)$ & & {$[0.13]$} & {$[0.52]$} \\
$1833-1864$ & -1.448 & -2.821 & 1.529 & 1.918 & 0.069 & -0.770 & 0.84 & 0.07 & 0.02 \\
& $(-0.90)$ & $(-1.61)$ & $(0.94)$ & $(1.05)$ & $(0.04)$ & $(-0.40)$ & & {$[0.79]$} & {$[0.89]$} \\
$1865-1913$ & -0.573 & $2.151^{\mathrm{b}}$ & -1.121 & 1.342 & 2.049 & 0.143 & 1.91 & 0.41 & 0.23 \\
& $(-0.53)$ & $(2.07)$ & $(-1.37)$ & $(1.38)$ & $(1.08)$ & $(0.08)$ & & {$[0.52]$} & {$[0.62]$} \\
$1923-2006$ & $-1.034^{\mathrm{c}}$ & $1.501^{\mathrm{c}}$ & $-0.936^{\mathrm{b}}$ & $1.728^{\mathrm{c}}$ & 0.659 & $1.118^{\mathrm{a}}$ & -0.45 & 0.21 & 0.12 \\
& $(-2.81)$ & $(4.12)$ & $(-2.28)$ & $(4.25)$ & $(1.21)$ & $(1.70)$ & & {$[0.64]$} & {$[0.72]$} \\
$1923-1936$ & 0.323 & $1.793^{\mathrm{c}}$ & $-1.918^{\mathrm{c}}$ & $1.725^{\mathrm{c}}$ & $2.245^{\mathrm{c}}$ & -0.203 & 2.45 & $7.95^{\mathrm{c}}$ & 0.01 \\
& $(0.81)$ & $(4.44)$ & $(-6.05)$ & $(4.55)$ & $(3.79)$ & $-(0.45)$ & & {$[0.005]$} & {$[0.92]$} \\
$1948-2006$ & $-1.118^{\mathrm{b}}$ & $2.273^{\mathrm{c}}$ & $-1.330^{\mathrm{a}}$ & 0.527 & 1.615 & -1.122 & 2.74 & $3.00^{\mathrm{a}}$ & $4.12^{\mathrm{b}}$ \\
& $(-2.29)$ & $(4.61)$ & $(-1.99)$ & $(0.97)$ & $(1.67)$ & $(-1.14)$ & & {$[0.08]$} & {$[0.042]$} \\
\hline
\end{tabular}

Notes: $t$-values in parentheses. The letters indicate significance at $10 \%=\mathrm{a}, 5 \%=\mathrm{b}$, and $1 \%=\mathrm{c}$. The coefficients and standard errors reported are from the solved static state of Eq. (4). All models are estimated with two lags of the dependent variable. The regressions have war impulse dummies 1854 and 1856, and 1939, 1940, 1945 and 1946. Detailed regression results are available on request. The de-trending of GDP per capita was done with the Hodrick-Prescott filter. The adjustment parameter was set to 6.25, following the recommendation of Ravn and Uhlig (2002). 